Review

\title{
Impaired Hematopoiesis after Allogeneic Hematopoietic Stem Cell Transplantation: Its Pathogenesis and Potential Treatments
}

\author{
Masahiro Imamura
}

check for

updates

Citation: Imamura, M. Impaired Hematopoiesis after Allogeneic Hematopoietic Stem Cell

Transplantation: Its Pathogenesis and Potential Treatments. Hemato 2021, 2 , 43-63. https://doi.org/10.3390/ hemato2010002

Academic Editor: Michèle Sabbah Received: 30 November 2020 Accepted: 29 December 2020 Published: 2 January 2021

Publisher's Note: MDPI stays neutral with regard to jurisdictional clai$\mathrm{ms}$ in published maps and institutional affiliations.

Copyright: () 2021 by the author. Licensee MDPI, Basel, Switzerland. This article is an open access article distributed under the terms and conditions of the Creative Commons Attribution (CC BY) license (https:// creativecommons.org/licenses/by/ $4.0 /)$.
Department of Hematology, Sapporo Hokuyu Hospital, Sapporo 003-0006, Japan; mimamura@med.hokudai.ac.jp

\begin{abstract}
Impaired hematopoiesis is a serious complication after allogeneic hematopoietic stem cell transplantation (allo-HSCT). Bone marrow aplasia and peripheral cytopenias arise from primary and secondary graft failure or primary and secondary poor graft function. Chimerism analysis is useful to discriminate these conditions. By determining the pathogenesis of impaired hematopoiesis, a timely and appropriate treatment can be performed. Hematopoietic system principally consists of hematopoietic stem cells and bone marrow microenvironment termed niches. Abnormality in hematopoietic stem and progenitor cells and/or abnormality in the relevant niches give rise to hematological diseases. Allo-HSCT is intended to cure each hematological disease, replacing abnormal hematopoietic stem cells and bone marrow niches with hematopoietic stem cells and bone marrow niches derived from normal donors. Therefore, treatment for graft failure and poor graft function after allo-HSCT is required to proceed based on determining the pathogenesis of impaired hematopoiesis. Recent progress in this area suggests promising treatment manipulations for graft failure and poor graft function.
\end{abstract}

Keywords: allogeneic hematopoietic stem cell transplantation; impaired hematopoiesis; graft failure; poor graft function; graft-versus-host disease; hematopoietic stem cells; bone marrow niches

\section{Introduction}

Allogeneic hematopoietic stem cell transplantation (allo-HSCT) is an essential therapy to cure many hematological diseases. However, there are several obstacles that should be overcome to obtain better outcome. Although graft-versus-host disease (GVHD) is the most frequently observed complication after allo-HSCT, impaired hematopoiesis should be also controlled along with some other complications such as relapse of the underlying diseases, infections (mostly viral infections), and so on. When no recovery of hematopoiesis (i.e., absolute neutrophil count $\geq 500 / \mu \mathrm{L}$ and/or platelet count $\geq 3 \times 10^{4} / \mu \mathrm{L}$ ) until day 28 lasting for at least three consecutive days is seen, urgent decision of appropriate treatment is required to ensure a definite hematopoietic recovery. No or delayed recovery of hematopoiesis (cytopenias) is caused by graft failure and poor graft function.

Graft failure and poor graft function can be primary and secondary, respectively. Graft failure incidence occurs in 5.6\% of patients who underwent allo-HSCT [1]. Primary graft failure indicates no initial donor engraftment and no initial hematopoiesis, resulting in hypocellular marrow and peripheral cytopenias under mixed or full recipient chimerism. In contrast, a temporal hematological recovery is seen after initial donor engraftment in secondary graft failure, showing hypocellular marrow and peripheral cytopenias under mixed or full recipient chimerism. Primary graft failure can be induced by the following factors: T-cell depleted hematopoietic stem cell graft, insufficient amount of hematopoietic stem cell graft, reduced immunosuppression, type of GVHD prophylaxis, stem cell source, female donor grafts for male recipients, HLA-mismatched graft, presence of donor-specific anti-HLA antibody, major ABO incompatibility, recipients with myeloproliferative diseases, disease status in patients at transplantation, patient's age, use of myelocytotoxic drugs, presence of septicemia, and presence of viral infections [1,2]. 
Poor graft function occurs in 5.0-27.0\% [3,4] and it is associated with GVHD, viral infections, use of myelocytotoxic drugs, patient's age, unrelated donor status, HLA-mismatched donor, mycophenolate mofetil use, and lower CD $34^{+}$cell dose [5]. Among those, GVHD is the major risk factor for poor graft function observed in $14 \%$ of 171 recipients of an HLA-matched bone marrow transplantation [6]. Primary poor graft function occurs after initial donor engraftment but no initial hematological recovery, resulting in hypocellular marrow and peripheral cytopenias under full donor chimerism. Hypocellular marrow and peripheral cytopenias are seen after initial donor engraftment and initial hematological recovery in secondary poor graft function under full donor chimerism. All four conditions require no evidence of disease relapse. Thus, chimerism analysis is important to choose an appropriate treatment, discriminating graft failure from poor graft function. Here, I will focus on the pathogenesis of impaired hematopoiesis after allo-HSCT and possible therapeutic manipulations.

\section{Importance of Chimerism Analysis for Determination of Graft Failure and Poor Graft Function}

Chimerism analysis based on polymerase chain reaction amplification of variable number tandem repeat or short tandem repeat allows the detection of imminent graft failure (rejection), poor graft function, or disease recurrence [7,8]. Graft failure can be discriminated from poor graft function by analyzing chimerism status as well as bone marrow and peripheral blood recovery. When cytopenias are present around day 28 after allo-HSCT, it is important to analyze the chimerism status to determine whether impaired hematopoiesis is caused by graft failure or poor graft function. Full recipient or mixed chimerism leads to primary graft failure or secondary graft failure. Mixed chimerism is composed of three different types depending on the extent of residual recipient cells; namely, decreasing, stable, and increasing mixed chimerism [9]. Bader et al. [10] suggest that decreasing mixed chimerism requires weekly follow-up until establishing complete chimerism $(>97 \%$ to $>99 \%$ of donor cells). Stable mixed chimerism requires weekly monitoring during engraftment including T-cell and NK-cell chimerism and thereafter bimonthly monitoring to realize late graft rejection. Increasing mixed chimerism requires weekly monitoring during the first 200 days (since most relapses occur during this period in patients with acute leukemia). Pre-emptive immunotherapy in patients with hematological malignant diseases is recommended when recipient cells exceed $5 \%$. On the other hand, it is recommended when recipient cells exceed $30 \%$ in patients with non-malignant diseases.

Another frequently observed phenomenon is split chimerism in which donor cells are not detectable in all cell compartments, whereas some cell compartments are completely recipient origin [10]. This split chimerism often occurs in patients with severe combined immunodeficiency or in patients transplanted with reduced intensity conditioning regimens. Therefore, it is important to analyze chimerism not only in whole peripheral blood or bone marrow cells but also in lineage-specific subpopulations. Initially, the importance of chimerism analysis in T cells was indicated by the findings that patients with $>90 \%$ donor T cells developed more frequently acute GVHD than did patients with $<90 \%$ donor $\mathrm{T}$ cells [11] and patients with $<90 \%$ donor $\mathrm{T}$ cells had rejection and relapse more frequently than did patients with $>90 \%$ donor T cells [12]. On the contrary, Guimond et al. [13] demonstrated that mixed chimerism in T-cell and NK-cell subpopulations were frequently found in pediatric patients with leukemia relapse, but not in children in remission. In contrast, mixed chimerism in these subpopulations was not found in adult patients with relapse. Pediatric patients with mixed chimerism in T-cell and NK-cell subpopulations on day 28 seemed to be more likely to reject the graft [14]. Bornhäuser et al. [15] demonstrated that patients with NK-cell donor chimerism $<75 \%$ on days $10-30$ after allo-HSCT more often rejected their grafts than those with $>75 \%$. Baron et al. [16] demonstrated that T-cell and NK-cell chimerism levels below $50 \%$ were significantly associated with higher risk for graft rejection.

We analyzed donor-type chimerism in $\mathrm{CD}^{+}, \mathrm{CD} 14 / 15^{+}$, and $\mathrm{CD}^{2} 6^{+}$cells from patients who underwent allo-HSCT with myeloablative or non-myeloablative conditioning 
regimens by PCR amplification of four types microsatellites (D3S1359, D6S89, ACTBP2, and HGH) [17]. More frequent mixed chimerism on day 28 was observed in all fractions from patients transplanted with non-myeloablative conditioning regimens and in $\mathrm{CD}^{+}$cells from patients transplanted with a non-total body irradiation (TBI) regimen. TBI-containing myeloablative conditioning regimens induced faster engraftment and full donor chimerism in all fractions than did non-TBI containing myeloablative conditioning regimens. Patients who had $>50 \%$ donor-type chimerism in $\mathrm{CD}^{+}$cells on day 14 frequently developed acute GVHD (>grade II), and patients who had donor-type chimerism $<50 \%$ in $\mathrm{CD}_{5} 6^{+}$cells on day 14 had more frequent graft failure. Furthermore, patients $<75 \%$ donor-type cells in all fractions on day 28 frequently developed graft failure and relapse. Patients transplanted with non-myeloablative regimens and showed $>50 \%$ donortype chimerism on day 14 had more frequently acute GVHD (grade II to IV) than those with $<50 \%$ donor-type chimerism. In mixed chimerism in CD14 $/ 15^{+}$and CD56 $6^{+}$cells on days 14 and 28, decreasing mixed chimerism is a favorable marker for better overall survival, while increasing mixed chimerism is not. In patients with increasing mixed chimerism, some additional treatment should be considered. Although tapering and withdrawal of immunosuppressive drugs or donor-lymphocyte infusion (DLI) are occasionally performed, the effect appears to be vague. These results suggest that the extent of donortype chimerism in lineage-specific cells show an impact on outcome in allo-HSCT. Thus, the chimerism analysis provides important information as to when prompt therapeutic interventions should be made.

Recently, new methods using next-generation sequencing and crystal digital PCR which are more sensitive and accurate than conventional methods for analyzing chimerism status have been developed [18]. Therefore, these methods will be widely used for chimerism analysis in the future.

\section{Factors Mediating Graft Failure and Poor Graft Function}

\subsection{Involvement of $\mathrm{T}$ Cells and NK Cells}

Graft failure is caused by residual host immunity (i.e., alloreactive immune responses), mainly mediated by T cells and NK cells [19]. T-cell-mediated graft rejection can occur in both HLA-mismatched and HLA-matched settings [20,21]. Although residual host CD8 ${ }^{+} \mathrm{T}$ cells are a major effector for graft rejection, residual host $\mathrm{CD} 4^{+} \mathrm{T}$ cells can reject graft and $\mathrm{NK}$ cells also play an important role in graft rejection via defective inhibitory receptor function of NK cells [22-28]. $\mathrm{CD}^{+}$and $\mathrm{CD} 4^{+}$T-cell-mediated graft rejection were associated with massive infiltration in the bone marrow of these cells secreting interferon (IFN)- $\gamma[29,30]$. Furthermore, $\mathrm{CD}^{+}$T-cell-mediated rejection was unable to be induced through perforin, Fas ligand (FasL), tumor necrosis factor receptor (TNFR) 1, and tumor necrosis factorrelated apoptosis-inducing ligand (TRAIL), tumor necrosis factor-like weak inducer of apoptosis, and tumor necrosis factor-like ligand 1A [31,32]. NK-cell-mediated rejection, mainly observed in major histocompatibility complex (MHC)-mismatched transplantations, is the result of a "missing-self recognition," when the inhibitory receptors expressed on donor NK cells, belonging to host Ly49 family in mice and to the killer immunoglobulin-like receptors (KIRs) in humans, fail to recognize their cognate MHC class I molecule on host cells [33]. Graft rejection by host NK cells, at least partially, depends on perforin-mediated cytotoxicity [34,35]. NK cells also express activating receptors such as CD226 [36,37] and natural killer group 2D (NKG2D) [38]. The balance of activating and inhibitory signals determines NK-cell activation against target cells [39]. Accordingly, donor T cells and NK cells facilitate donor hematopoietic stem cell engraftment through inhibiting residual host immunity. However, an opposite finding was reported by demonstrating that rapid expansion of donor $\mathrm{T}$ cells suppressed hematopoiesis derived from donor hematopoietic stem cells [40]. This controversial observation appears to be caused by the difference of Tcell dose in infused hematopoietic cells which may correlate to the severity of acute GVHD. 


\subsection{Involvement of Regulatory $T$ Cells}

$\mathrm{CD} 4{ }^{+} \mathrm{CD} 25^{+}$regulatory $\mathrm{T}$ cells (Tregs) are not restricted to their regulatory actions within adaptive and innate immune systems, thus suggesting that the ability of these cells to inhibit progenitor cell activity illustrates the complex interactions between the immune system and hematopoietic compartments. Namely, negative regulation of myeloid progenitors can occur in the presence of Tregs after ablative conditioning and allo-HSCT through transforming growth factor (TGF)- $\beta$. Thus, the intentional addition (i.e., donor) and / or deletion (i.e., recipient) of this population may be important to consider within the context of the hematopoietic and immunologic reconstitution of the patient after alloHSCT [41]. Similarly, TGF- $\beta$ is also involved in Treg engraftment facilitation as anti-TGF- $\beta$ monoclonal antibody treatment prior to allo-HSCT led to a significant increase in NK-cellmediated graft rejection, suggesting that Tregs mediate NK-cell suppression through TGF$\beta$ [42]. Accordingly, adoptive transfer of host-type Tregs improved durable engraftment of allogeneic bone marrow grafts $[43,44]$. High-resolution in vivo imaging showed, marked co-localization of hematopoietic stem cells with host Tregs on the endosteal surface in the calvarial and trabecular bone marrow. However, hematopoietic stem cells were lost by depletion of Tregs, suggesting a direct effect of Tregs in bone marrow niche generation and maintenance [45]. This effect seems to be essentially dependent on interleukin (IL)10 production by Tregs. Recently, bone marrow Tregs have been reported to mediate stromal cell function and support hematopoiesis via IL-10 [46]. Following Treg depletion, the function and phenotype of both mesenchymal stromal cells (MSCs) and hematopoietic stem cells was impaired. Transplantation also revealed that a Treg-depleted niche has a reduced capacity to support hematopoiesis. Bone marrow Tregs are high producers of IL-10 and Treg-secreted IL-10 has direct effects on MSC function.

Treg-based cellular therapies are still limited because of the difficulties to isolate them from peripheral blood in sufficient amounts. Use of ex vivo expanded third-party Tregs [47] or pharmacological approaches using low-dose IL-2 [48-51], IL-2/anti-IL-2 monoclonal antibody complexes [52] and keratinocyte growth factor (KGF) [53] to induce Treg expansion in vivo may be utilized.

Koreth et al. [48] investigated whether low-dose IL-2 could preferentially enhance Tregs in vivo and suppress clinical manifestations of chronic GVHD, since IL-2 is critical for Treg cell growth, survival, and activity [54]. Daily low-dose IL-2 was safely administered in patients with active chronic GVHD that was refractory to steroid therapy, showing sustained Treg expansion in vivo and amelioration of the manifestations of chronic GVHD. The mechanism of this phenomenon is mediated by selective increase of signal transducer of transcription 5 (STAT5) phosphorylation in Tregs and a decrease of phosphorylated STAT5 in $\mathrm{CD}^{+}{ }^{+} \mathrm{T}$ cells, thus restoring the homeostasis of $\mathrm{CD}^{+} \mathrm{T}$-cell subsets and promotes the reestablishment of immune tolerance [49]. On the contrary, Xhao et al. [50] and Betts et al. [51] suggested that low-dose IL-2 therapy required still caution. Although administration of a complex of IL-2 and anti-IL-2 antibody enhanced donor chimerism early as well as long-term engraftment following non-myeloablative conditioning regimen and MHC-matched allo-HSCT, timing of administration of this complex was crucial: administration of this complex post-HSCT more efficiently facilitated engraftment than pre-HSCT. Importantly, this approach clearly suppressed the emergence of host anti-donor $\mathrm{CD}^{+} \mathrm{T}$ cells by the transient activation and expansion of recipient Tregs [52]. Efficacy of low-dose IL-2 therapy may be expected to some extent; however, more investigation is required to obtain a sufficient and reliable conclusion.

\subsection{Involvement of Mesenchymal Stem Cells}

Mesenchymal stem cells (MSCs), which can be obtained from bone marrow, umbilical cord, and adipose tissue, have the capacity to differentiate in vitro and in vivo into several mesenchymal tissues, including bone, cartilage, tendon, muscle, adipose tissue, and, possibly, bone marrow stroma [55,56]. MSCs possess the following characteristics [56]. MSCs seem to escape the immune system. Adult MSCs express intermediate levels of 
HLA major histocompatibility complex (MHC) class I molecules and do not express HLA class II antigens of the cell surface [57]. MSCs possess multiple effects on immune cells as follows: increase in Tregs and IL-10 production, decreasing IFN- $\gamma$ production by Thelper cell type 1, increasing IL-4 production by T helper cell type [58], inhibition of mixed lymphocyte cultures and subsequent development of cytotoxic $T$ cells by soluble factors [59], production of IL-6, IL-8, stem-cell derived factor 1, and vascular endothelial growth factor, inhibition of T-cell activation by prostaglandin $E_{2}$ which induces Tregs [56,58], production of indoleamine 2,3-dioxygenase which is induced by IFN- $\gamma$ which catalyzes the conversion from tryptophan to kynurenine and inhibits T-cell responses [60], inhibition of T-cell responses by TGF- $\beta$ [59], hepatocyte growth factor, and IL-2, induction of macrophage differentiation from M1 to M2 [56,61], delayed maturation of antigen presenting cells [62], decreased expression of HLA-DR, suppression of B-cell responses [63], secretion of HLA-G which interacts with inhibitory receptors on NK cells [64], suppressed differentiation of naïve $T$ cells into Th-17 cells [65].

Furthermore, MSCs are key players in the bone marrow stem cell niche [66]. Following the transplantation of mouse bone marrow MSCs under the kidney capsule, the MSCs formed several crucial niche elements such as osteoblasts, adipocytes, and reticular fibroblasts that recruited HSCs and sustained hematopoiesis in the recipient [66]. MSCs contribute to the formation of the bone marrow niche, thus providing an appropriate microenvironment for control of the maturation, differentiation, and survival of blood-born cells [67]. MSCs support hematopoiesis and colocalize with HSCs during ontogeny [68].

Almeida-Porada et al. [69] demonstrated that co-transplantation of human stroma cell progenitors into preimmune fetal sheep resulted in early appearance of human donor cells in circulation and enhanced cell levels in the bone marrow at later time points after transplantation. Lazarus et al. [70] demonstrated that co-transplantation of HLA-identical sibling culture-expanded mesenchymal stem cells and hematopoietic stem cells in patients with hematologic malignancies were feasible and safe, indicating a need for further investigations. In case of patients with higher risk of graft failure and poor graft function, co-transplantation of MSCs may be warranted as shown in several human studies [71-75]. However, efficacy of co-transplantation of MSCs in allo-HSCT is still controversial [76-78] because of the weak study design and small study populations in previous clinical studies $[79,80]$, although it appears that the infusion of MSCs has been shown to be safe and well-tolerated in humans with a slightly positive trend for overall survival [80]. In order to prove the efficacy of co-transplantation of MSCs, well-designed larger clinical studies are required.

MSCs possess immunoregulatory function as wells as engraftment-enhancing function [56]. Therefore, MSCs can be utilized for prevention of acute and chronic GVHD as well as graft failure.

Le Blanc et al. [81] first reported that severe acute GVHD was successfully treated with third party haploidentical MSCs. We have also used bone marrow-derived third party MSCs (JR-031) for steroid-refractory grade III or IV acute GVHD in 25 patients (grade III 22 patients and grade IV, 3 patients), resulting in $24 \%$ CR and $36 \%$ PR, respectively [82]. MSCs did not seem to inhibit a graft-versus-leukemia effect. Adverse effects commonly associated with MSC infusions were not observed. Furthermore, Kurzuberg et al. [83] reported a similar effect in pediatric patients who had steroid-refractory acute GVHD after allo-HSCT. Among several MSCs, placenta-derived decidua stromal cells appear to be more effective than bone marrow-derived MSCs for treatment of severe acute graft-versus-host disease [84].

\subsection{Donor-Specific Anti-HLA Antibody}

Humoral immunity is also related to graft rejection and delayed engraftment. Donorspecific HLA antibodies (DSA) can cause primary graft failure in HLA-mismatched and haploidentical transplantations [85-90]. Integrated humoral and cellular immunity against the same alloantigen of the donor can mediate graft rejection in DSA-positive patients 
who underwent HLA-mismatched cord blood transplantation [91]. Furthermore, other donor-specific antibody against CD $34^{+} / \mathrm{VEGFR}-2^{+}$endothelial progenitor stem cells causes primary graft rejection [92].

The treatments to desensitize patients with DSA are classified into the following four strategies: 1. Antibody removal by using plasmapheresis or immunoabsorption; 2 . inhibition of antibody production by using rituximab, and proteasome inhibitor against alloantibody-producing plasma cells (bortezomib); 3. antibody neutralization using intravenous immunoglobulin, or with donor HLA antigens (platelet transfusions or white blood cell infusion in the form of an irradiated buffy coat); and 4. inhibition of complement cascade [90]. Plasmapheresis is the most common method of desensitization; however, plasmapheresis alone does not effectively prevent graft failure. Therefore, combination therapy is essential. Plasamapheresis plus rituximab or intravenous immunoglobulin, or plasamapheresis plus intravenous immunoglobulin plus tacrolimus are effective desensitization treatments for a strong DSA $[85,86,88-90]$. Platelet transfusion was the most simple and effective treatment option for class I DSA $[86,90]$.

\section{Involvement of Pro-Inflammatory Cytokines in Graft Failure and Poor Graft Function}

Among several pro-inflammatory cytokines, IFN- $\gamma$ and tumor necrosis factor (TNF)- $\alpha$ are critical cytokines that inhibit hematopoiesis through apoptosis of hematopoietic stem and progenitor cells (HSPCs) and/or inhibition of cell proliferation and differentiation.

\subsection{Interferon- $\gamma$}

Mori et al. [93] showed that the Fas expression in both hematopoietic progenitor cells and whole bone marrow cells increased in case of acute GVHD but not chronic GVHD, resulting in apoptosis of hematopoietic cells through Fas in a murine GVHD model. In fact, anti-Fas antibody treatment protected the recipient mice from bone marrow failure. IFN- $\gamma$ produced by alloreactive $\mathrm{T}$ cells may entail a severe GVH reaction and could be responsible for cytopenias that are frequently observed in subjects with GVHD [94]. FasL-dependent apoptosis and decreased donor cell proliferation is responsible for spleen hypoplasia. Blockade of Fas/FasL interaction by the use of anti-FasL blocking antibodies significantly reduced cytopenias and bone marrow aplasia. Antibody-mediated IFN- $\gamma$ neutralization reversed blood cytopenias [95]. Increased apoptosis of HSPCs through Fas/FasL pathway, caspases, and related proapoptotic genes by increased IFN- $\gamma$ is frequently observed in murine GVHD models $[30,83-86,96-99]$ and human allo-HSCT $[99,100]$.

Merli et al. [99] showed that anti-IFN- $\gamma$ monoclonal antibody (emapalumab) treatment promoted donor cell engraftment in 2 out of 3 children with primary hemophagocytic lymphohistiocytosis (HLH) who, after experiencing graft failure, were re-transplanted from the same HLA-haploidentical donor under the compassionate use coverage of emapaulimab, an anti-IFN- $\gamma$ monoclonal antibody recently approved by the US FDA for treatment of patients with primary HLH. In murine study, anti-IFN- $\gamma$ monoclonal antibody treatment promoted donor cell engraftment. These results suggested that the IFN- $\gamma$ pathway played a major role in graft failure occurring after allo-HSCT, and provided the rationale for exploring the therapeutic/preventive role of targeted neutralization of IFN- $\gamma$.

Lin et al. [97] studied the kinetics of hematopoiesis and the functions of HSPCs in an acute GVHD model. Although hematopoiesis was progressively suppressed during acute GVHD, the hematopoietic regenerative potential of donor-derived hematopoietic stem cells remains intact. There was a dramatic reduction in primitive hematopoietic cells and a defect in the ability of these cells to generate common myeloid progenitors (CMPs) and megakaryocyte/erythrocyte progenitors (MEPs). These effects were observed along with a concomitant increase in granulocyte/macrophage progenitors, suggesting that differentiation into MEPs is blocked during acute GVHD. The serum levels of Th1 cytokines, including IL- $1 \alpha$, IL-2, and IFN- $\gamma$, were significantly higher in the acute GVHD mice than in control mice. Because elevated Th1 cytokine levels are a key indicator of donor T-cell proliferation and differentiation, they investigated whether inhibiting T-cell immunity 
could attenuate the hematopoietic suppression associated with acute GVHD. Cyclosporine A was able to partially reverse the hematopoietic suppression as well as the differentiation blockage of CMPs. Chen et al. [98] reported that the activity of IFN- $\gamma$ on murine hematopoiesis is context dependent. IFN- $\gamma$-augmented apoptotic gene (Fas, caspases, and related proapoptotic genes) expression facilitated destruction of HSPCs in the presence of activated cytotoxic T cells, as occurs in human bone marrow failure. Wang et al. [100] reported the polarization of $\mathrm{CD} 4^{+}$and $\mathrm{CD} 8^{+} \mathrm{T}$ cells toward a type 1 pattern in poor graft function. Dysregulated T-cell responses may contribute to the occurrence of poor graft function after allo HSCT.

Recently, Tucci et al. [101] have reported a case of secondary HLH-related graft failure in the context of HLA-haploidentical HSCT successfully treated with emapalumab in the presence of concomitant life-threatening infections, including disseminated tuberculosis. This seminal case supports emapalumab use for treatment of secondary HLH and prevention of graft failure in patients underwent haploidential HSCT even in the presence of multiple infections.

IFN- $\gamma$ is a potent negative regulator of HSPCs [102-106]; therefore, increased IFN- $\gamma$ exerts a non-MHC restricted inhibitory action on HSPCs [94,95]. IFN- $\gamma$ appears to facilitate apoptosis of HSPCs either directly or through induction of caspase-1, tumor necrosis factor-related apoptosis-inducing ligand, and Fas $[106,107]$. In addition, IFN- $\gamma$ inhibits self-renewal of hematopoietic stem cell modulating expression of key cell-cycle genes, such as cyclin D1 [94,108], Myc [94], and p57 [108]. IFN- $\gamma$-mediated cyclin D1 suppression appears to affect the immature HSPCs but not mature hematopoietic cells. Furthermore, IFN- $\gamma$ interferes with thrombopoietin-induced phosphorylation of STAT5 in hematopoietic stem cells through modulation of suppressor of cytokine signaling 1 [108].

\subsection{Tumor Necrosis Factor- $\alpha$}

Tumor necrosis factor (TNF)- $\alpha$ is also a pro- inflammatory cytokine that negatively regulates the growth of murine and human hematopoietic progenitors [109-112]. A negative effect of TNF- $\alpha$ on hematopoietic stem cell maintenance by enhancing their differentiation rather than self-renewal has been suggested [113]. The negative effect of TNF- $\alpha$ was not dependent on the Fas/FasL pathway [113], although markedly increased Fas antigen expression on $\mathrm{CD}^{+} 4^{+}$hematopoietic stem cells was induced by stimulation with TNF- $\alpha$ and IFN- $\gamma$, and anti-Fas antibody rescued bone marrow failure [93,94]. Like many other inflammatory diseases, bone marrow failure is associated with TNF- $\alpha$ overexpression. In murine lymphocyte infusion-induced bone marrow failure models but not allo-HSCT models, treatment with anti-TNF- $\alpha$ monoclonal antibody induced significant prolongation of survival although less impressive than using anti-IFN- $\gamma$ monoclonal antibody treatment [29]. Furthermore, using mice deficient for either TNF receptor super family 1a (Tnfrsf1a) receptor or Tnfrsf1b receptor or both, a TNF- $\alpha$-mediated suppression of hematopoietic stem cell activity was shown [114]. In vivo administration of TNF- $\alpha$ targeted cycling rather than quiescent hematopoietic stem cells. In fact, blockade of TNF- $\alpha$ using etanercept, which is a soluble TNF- $\alpha$ receptor 2 and competes for TNF- $\alpha$ binding, early after transplant appears to limit a cytokine-mediated suppressive effect on repopulating cell function, thus facilitating engraftment [115]. TNF- $\alpha$ from host macrophages and TNF- $\alpha$ receptor expressed on donor T cells are critical in the pathogenesis of murine immune-mediated bone marrow failure $[115,116]$. Aplastic anemia patients have higher frequencies of TNF- $\alpha$ producing $\mathrm{CD} 16^{+} \mathrm{CD} 68^{+}$macrophages in the bone marrow than healthy controls. In clinical settings, anti-TNF- $\alpha$ antibody treatment or use of TNF- $\alpha$ blockade may be effective for graft failure and poor graft function, but the efficacy was limited even in combination with other immunosuppressive drugs $[117,118]$.

\section{Damage of Hematopoietic Stem/Progenitor Cells and Bone Marrow Microenvironment in Graft Failure and Poor Graft Function}

Hematopoiesis depends on special bone marrow microenvironment termed niches in which HSCs reside as well as on the functional crosstalk between hematopoietic stem cells 
and these niches [119]. Early studies suggested that bone marrow endosteal, perivascular and vascular endothelial cells as well as osteoblasts have a fundamental role in the maintenance of hematopoietic stem cells by providing signals that regulate cell self-renewal, differentiation, and quiescence in mice [120]. However, recent studies showed that the hematopoietic niches are more complex [121]. There are various cell types and niche factors that directly or indirectly regulate hematopoietic stem cell activity $[120,121]$. Periarteriolar nestin (Nes)-green fluorescent protein (GFP) ${ }^{\text {high }}$ cells, neural-glial antigen 2-positive cells, myosin heavy chain 11-positive cells, perisinusoidal Nes-GFPlow cells, CXC-chemokine ligand 12 (CXCL12)-abundant reticular (CAR) cells and leptin receptor-positive cells are key regulators of hematopoietic stem cell maintenance [122-125]. Furthermore, sympathetic nervous system nerves regulate hematopoietic stem cell mobilization, and nonmyelinating Schwann cells may contribute to hematopoietic stem cell quiescence [126,127]. Osteoblasts may have a role in regulating lymphoid progenitors [128]. Adipocytes may negatively affect hematopoietic stem cell maintenance [129]. Hematopoietic cells, such as macrophages, neutrophils, Treg cells and megakaryocytes can contribute to hematopoietic stem cell maintenance or mobilization [120,121]. Regional localization of hematopoietic stem cell subsets has shown that platelet-biased or myeloid-biased von Willebrand (Vwf)-GFP ${ }^{+}$ hematopoietic stem cells and $V w f-\mathrm{GFP}^{-}$hematopoietic stem cells may be located in and regulated by separate bone marrow niches containing megakaryocytes and arterioles, respectively $[120,121]$.

Graft failure and poor graft function can be induced by not only HSPC but also bone marrow microenvironment (niches) damage.

We showed that donor effector $\mathrm{CD}^{+}$, and to a lesser extent $\mathrm{CD} 8^{+}, \mathrm{T}$ cells caused early destruction of osteoblasts, and dysfunction of vascular niches and CAR cells (qualitatively, but not quantitatively), leading to bone marrow suppression and severe impairment of B lymphopoiesis with dramatically decreased numbers of B-cell precursors and decreased expression of transcriptional factors essential for B lymphopoiesis, such as E2A and PAX5 in a murine acute GVHD model [130]. Anti-CD4 monoclonal antibody treatment ameliorated bone marrow failure and B lymphopoiesis preserving graft-versus-tumor effect. The most controversial cellular components of the bone marrow niche are osteoblasts, as initial studies pointed toward their regulatory role in hematopoietic maintenance [121]. Since 3D imaging studies have shown that endogenous hematopoietic stem cells are not significantly associated with osteoblasts, mature osteoblasts do not have a direct role in regulating hematopoietic stem cell activity [131,132]. However, osteolineage cells seem to support the maintenance of more committed hematopoietic progenitors, in particular, the lymphoid lineage. Osteoblasts are both necessary and sufficient for murine B-cell commitment and maturation, and thereby constitute the cellular homolog of the avian bursa of Fabricius [133]. There are several reports regarding impaired B lymphopoiesis accompanied with murine GVHD [134] and human GVHD [135,136]. These phenomena appear to be partially related to bone marrow niche damage. In our case, acute GVHD injured osteoblasts and/or other hematopoietic niches including vascular niches and CAR cells, although IL-1, IFN- $\gamma$, and TNF- $\alpha$ did not play an important role for exerting impaired hematopoiesis and B lymphopoiesis. The Fas/FasL pathway appears to be partially related to bone marrow suppression and impaired B lymphopoiesis. Similarly, decreased osteoblasts and cytopenias were observed in allo-HSCT patients with chronic GVHD, accompanied with an increasing CD4/CD8 ratio [137].

Other reports on damage of bone marrow niches causing GVHD-associated graft failure or poor graft function are shown in Table 1. Kong Y et al. [138,139] reported that acute and chronic GVHD in patients after allo-HSCT induced injury of osteoblasts, vascular, and perivascular niches as well as HSPCs. The patients with poor graft function showed markedly hypocellular marrow with scattered hematopoietic cells and significantly lower CD $34^{+}$cells, endosteal cells, perivascular cells, and endothelial progenitor cells compared with good graft function allo-HSCT recipients. There was no difference between early and late poor graft function regarding damage of bone marrow niches. Yao et al. [140] 
showed that sinusoidal endothelial cells (SECs) is a target of acute GVHD in a murine GVHD model. High level of Fas and caspase-3 expression and high rate of apoptosis were identified in SECs, indicating that these were destroyed by acute GVHD. Furthermore, high FasL expression on engrafted donor $\mathrm{CD}^{+}$, but not $\mathrm{CD}^{+} \mathrm{T}$ cells, and high level of MHC class II but not MHC class I expression on SECs suggested that apoptosis was mediated by $\mathrm{CD}^{+}$donor T cells through the Fas/FasL pathway. Medinger M et al. [141] investigated whether acute GVHD might reduce the number of nestin+ perivascular bone marrow stem cell niche $\left(\mathrm{N}^{+} \mathrm{SCN}\right)$. They examined patients with AML who had undergone allo-HSCT. The number of $\mathrm{N}^{+} \mathrm{SCN}$ in bone marrow biopsies was significantly reduced in acute GVHD patients at the time of acute GVHD compared with patients who did not have acute GVHD. Cao et al. [142] reported that reduced and dysfunctional bone marrow endothelial progenitor cells (BM EPC), characterized by decreased migration and angiogenesis capacities and increased levels of reactive oxygen species (ROS) and apoptosis, were found in acute GVHD patients. Furthermore, lower frequency and increased levels of ROS, apoptosis and DNA damage were found in bone marrow CD34 ${ }^{+}$cells of acute GVHD patients. The severity of acute GVHD and GVHD-mediated cytopenia was associated with BM EPC impairment in acute GVHD patients. In addition, the EPC impairment positively correlated with ROS level. Thus, reduced and dysfunctional BM EPCs may be involved in the pathogenesis of acute GVHD, indicating that improvement of BM EPCs may represent a promising therapeutic approach for acute GVHD patients. Song et al. [143] reported that bone marrow MSCs from patients with poor graft function expanded more slowly and exhibited more apoptosis and senescence than MSCs from patients with good graft function. Increased intracellular ROS, p53, and p21 levels were found in MSCs from patients with poor graft function. Furthermore, the ability of MSCs to sustain hematopoiesis was significantly reduced in patients with poor graft function. This study suggests that improvement of bone marrow MSCs may represent a promising therapeutic approach for patients with poor graft function after allo-HSCT. Zhao et al. [144] reported that activated inflammatory macrophages increased in patients with poor graft function after allo-HSCT but anti-inflammatory macrophages decreased. Furthermore, increased intracellular levels of TNF- $\alpha$ and IL-12 were evident in bone marrow macrophages from patients with poor graft function, while decreased intracellular levels of TGF- $\beta$ were observed, leading to the occurrence of poor graft function.

For repairing the damage of bone marrow niches, administration of N-acetyl-Lcysteine (NAC) or atorvastatin is recommended as therapeutic manipulations. NAC is a ROS scavenger that can enhance the defective hematopoietic stem cells by repairing the dysfunction of bone marrow microenvironment $[145,146]$. Atorvastatin can enhance endothelial cell function in patients with poor graft function after allo-HSCT [147]. Atorvastatin downregulated the activated p38 and its downstream transcription factor, cyclic adenosine monophosphate-responsive element-binding protein, thereby repairing the dysfunction of bone marrow endothelial progenitor cells.

Table 1. Damage of bone marrow microenvironment by graft-versus-host disease (GVHD) after allogeneic hematopoietic stem cell transplantation (allo-HSCT).

\begin{tabular}{|c|c|c|c|c|}
\hline Studied in: & Type of GVHD & Target & References & Reported Year \\
\hline \multirow[t]{3}{*}{ Murine } & Acute & Osteoblasts & [130] Shono Y, et al. & 2010 \\
\hline & & Vascular niches & & \\
\hline & & CAR cells & & \\
\hline \multirow[t]{4}{*}{ Human } & Acute/chronic & Endosteal niches & [138] Kong Y, et al. & 2013 \\
\hline & & Vascular niches & & \\
\hline & & Perivascular niches & & \\
\hline & & ematopoietic stem ce & & \\
\hline Human & Chronic & Osteoblasts & [137] Shono Y, et al. & 2014 \\
\hline
\end{tabular}


Table 1. Cont.

\begin{tabular}{cccrc}
\hline Studied in: & Type of GVHD & Target & References & Reported Year \\
\hline Murine & Acute & Vascular niches & [140] Yao Y, et al. & 2014 \\
\hline Human & Acute & Perivascular niches & [141] Medinger M, et al. & 2015 \\
\hline Human & Acute & Endosteal niches & [139] Kong Y, et al. & 2016 \\
\hline \multicolumn{5}{c}{ Vascular niches } \\
\hline Puman & Perivascular niches \\
\hline Human & Hematopoietic stem cells & [142] Cao XN, et al. & 2018 \\
\hline
\end{tabular}

\section{Other Therapeutic Interventions for Graft Failure and Poor Graft Function}

\subsection{CD34+-Selected Stem Cell Boost}

In previous sections, potential usefulness of MSCs and Tregs as cellular therapies for graft failure and poor graft function were shown. One more promising manipulation is CD34 ${ }^{+}$-selected stem cell boost.

Larocca et al. [148] reported that in patients with poor graft function, a boost of CD34 ${ }^{+}$ selected peripheral blood donor cells is associated with a high chance of trilineage recovery (a rate of 75\%) and a low risk of acute GVHD and non-relapse mortality is lower when using peripheral blood cells for the boost. Klyuchnikov et al. [149] reported that hematological improvement was observed in $81 \%$ of 32 patients undergoing a CD34 ${ }^{+}$-selected stem cell boost without prior conditioning. The recipients of related grafts responded faster than recipients of unrelated grafts ( 20 versus 30 days). The cumulative incidence of acute (grade II to IV) and chronic GVHD after CD34 $4^{+}$-selected stem cell boost was $17 \%$ and $26 \%$, respectively. Patients with acute GVHD received a higher median $\mathrm{CD}^{+}$cell dose. The $2-$ year probability of overall survival was $45 \%$. Minardi et al. [150] reported 50 pediatric patients with poor graft function underwent a CD34 ${ }^{+}$-selected stem cell boost after alloHSCT. Within 8 weeks, a significant increase in median neutrophil counts and a decrease in red blood cell and platelet transfusion requirement were observed, and $78.8 \%$ of patients resolved one or two of their cytopenias. $36.5 \%$ had a complete hematological response. The rate of acute GvHD grade I-III was only $6 \%$ and resolved completely. No GvHD grade IV or chronic GvHD occurred. Mohty et al. [151] reported that post-transplant CD34 ${ }^{+}$-selected boost could be effective in restoring normal graft function in patients with poor graft function with full donor chimerism after allo-HSCT, including in those patients who received haploidentical stem cell transplant, allowing hematopoietic recovery without increase in GVHD. The complete response rate was $70 \%$ and the median time to response was 15 days with all responding patients recovering within the first month after boost. Cuadrago et al. [152] reported the outcome of 62 consecutive patients who had primary or secondary poor graft function who underwent a CD $34^{+}$-selected stem cell boost from the same donor without further conditioning. Forty-seven of 62 patients showed hematological improvement and became permanently transfusion and growth factor-independent. Recovery was similar in patients with mixed and full donor chimerism. Five-year overall survival was $74.4 \%$ in patients demonstrating complete recovery, $16.7 \%$ in patients with partial recovery and $22.2 \%$ in patients with no response.

\subsection{Eltrombopag}

Eltrombopag, a thrombopoietin-receptor agonist, which was first used for the treatment of chronic idiopathic thrombocytopenic purpura [153], has been added to first-line immunosuppressive therapy, significantly improving the hematopoietic recovery [154]. Recently, eltrombopag monotherapy has been shown to improve hematopoiesis in patients 
with low to intermediate risk-1 myelodysplastic syndrome, indicating that eltrombopag preferentially stimulates normal hematopoietic stem and progenitor cells [155].

In terms of pharmacological therapies for graft failure and poor graft function, antiIFN- $\gamma$ antibody appears to be efficacious but larger clinical studies are required. Efficacy of anti-TNF- $\alpha$ antibody treatment or use of TNF- $\alpha$ blockade appears to be limited. In contrast, efficacy of eltrombopag for poor graft function has been increasingly reported and seems to be promising. Although eltrombopag is basically more effective for poor graft function compared with graft failure probably because of its preferential stimulation of normal HSPCs [155], a further study is required to confirm this point.

Marotta et al. [156] reported a retrospective single-center experience with the thrombopoietinmimetic agent eltrombopag for the treatment of poor graft function. Thirteen patients have received eltrombopag for either poor graft function or primary graft failure. In the 12 poor graft function patients eltrombopag was started at the median time of 79 days after HSCT, due to persistent thrombocytopenia, with concomitant anemia and neutropenia in 7 and 3 patients, respectively. Hematological response was seen in 7 patients, with 6 complete responses. Hematological responses were seen both in patients with evidence of immunemediated pathophysiology, and with possible infectious/iatrogenic causes. In responding patients, eltrombopag was discontinued in 6 of 7 patients without further relapse. These results suggest that eltrombopag is safe and possibly effective in the setting of the treatment of poor graft function, and pave the way for future prospective studies. Fu et al. [157] reported that 38 patients treated with eltrombopag for refractory thrombocytopenia after haploidentical-HSCT. Eight patients had delayed platelet engraftment, 15 patients had secondary failure of platelet recovery, and 15 patients had poor graft function. The cumulative incidence of platelet recovery to transfusion independence was $63.2 \%$ and to $\geq 50 \times 10^{9} / \mathrm{L}$ without transfusion support was $52.3 \%$. Neutrophil counts and hemoglobin were also increased in the nine responders with poor graft function. Nineteen $(79.2 \%)$ of the 24 responders were able to taper off eltrombopag, and the remaining 5 patients were able to begin a taper. The median duration of treatment was 64 (range 14-195) days. The presence of megakaryocyte before initiation was the only independent factor influencing the efficacy of eltrombopag. Yuan et al. [158] reported 13 patients treated with eltrombopag for poor platelet engraftment without evidence of relapse at the time of initiation, including 6 patients with primary platelet engraftment failure and 7 with secondary platelet engraftment failure. The overall response rate was $62 \%$. Of the 6 patients with primary isolated platelet failure, 3 responded, and of the 7 patients with secondary platelet failure, 5 responded. The median time to response was 33 days (range, 11 to 68 days). In addition, no significant differences in platelet recovery were noted in patients with adequate and decreased bone marrow megakaryocytic reserve ( $60 \%$ and $67 \%$, respectively).

\section{Future Directions}

Hematological diseases were thought to be driven solely by genetic or epigenetic lesions within hematopoietic cells. However, the bone marrow niches that maintain and regulate daily production of blood and immune cells in the distinct interaction of different HSPCs are now increasingly being recognized as having an important role in the pathogenesis and chemoresistance of hematological diseases [159]. Allo-HSCT is a replacement therapy of both recipient hematopoietic stem cells and bone marrow niches by those derived from normal donors. Harmful conditions such as GVHD or persistent inflammation/infection to hematopoietic stem cells and bone marrow niches constructed from normal donor cells should be avoided to ensure a definite engraftment and prompt hematopoietic recovery. Occurrence of graft failure and poor graft function suggests a replacement failure due to damage of hematopoietic stem cells and/or bone marrow niches. Based on delineating the pathogenicity of graft failure and poor graft function, we are required to decide a prompt and appropriate treatment for curing each patient who underwent allo-HSCT. 
A recent report showed that donor healthy HSPCs transfer functional mitochondria to the stromal microenvironment, thus improving mitochondria activity in recipient MSCs. Mitochondrial transfer to MSCs is cell-contact dependent and mediated by HSPC connexin43 (Cx43). Recipient stromal microenvironment recovery and donor HSPC engraftment were augmented after mitochondria transfer. Healthy donor HSPCs not only reconstitute the hematopoietic system after transplantation but also support and induce the metabolic recovery of their damaged microenvironment via mitochondrial transfer [160] and vice versa $[161,162]$. This exchange of mitochondria results in Cx43-dependent scavenging of ROS from donor HSPCs [163] and the support of the metabolic activity of the recipient MSCs and their regenerative functionality, which further contribute to the success of the hematopoietic engraftment. These findings indicate $\mathrm{CD} 34^{+}$-selected stem cell boost and administration of MSCs have advantages to facilitate engraftment. CD34 ${ }^{+}$-selected stem cell boost appears to play important roles in increasing the number of hematopoietic stem cells as well as repairing stromal cells damaged by GVHD or persistent inflammation/infection. However, since it is still unclear whether the maintenance, differentiation, and proliferation of normal HSPCs can be regularly supported even though mitochondrial transfer from normal HSPCs can "functionally" normalize damaged recipient stromal cells; namely, it is unclear whether dysregulated function of recipient stromal cells can be completely corrected or not in the context of supporting normal hematopoiesis. Furthermore, it is unclear whether normal MSCs can correctly normalize abnormal hematopoietic stem cells. Therefore, recipient hematopoietic stem cells as well as stromal cells should be replaced by normal cells by allo-HSCT.

Possible treatments for graft failure and poor graft function are summarized in Table 2. Only treatment for primary graft failure is second transplant. According to recent clinical findings, treatment order for secondary graft failure appears to be CD $34^{+}$-selected stem cell boost, MSCs, eltrombopag, low dose IL-2, anti-IFN- $\gamma$ antibody, and second transplant; however, in case of active GVHD and inflammation/infection, MSCs are preferred to be used first. Tapering or withdrawal of immunosuppressive drugs, or DLI may be tried, although the efficacy is limited. Treatment for primary and secondary poor graft function appears to be CD34 ${ }^{+}$-selected stem cell boost, eltrombopag, MSCs, low-dose IL-2, anti-IFN$\gamma$ antibody, and second transplant. In case of active GVHD and inflammation/infection, MSCs are preferred to be used first, similarly to the order in secondary graft failure. Regarding administration of NAC or atorvastatin, clinical evidence is still lacking; therefore, future clinical studies are awaited. MSCs possess strong immunoregulatory activity as well as hematopoiesis-enhancing activity including bone marrow niche-remodeling capacity; therefore, administration of MSCs is appropriate for the treatment of patients who are suffering from severe GVHD or inflammation/infection, and who have damage of bone marrow niches. Eltrombopag seems to be more effective in the patients with full donor chimerism status than those with mixed chimerism status because of its preferential stimulation to normal HSPCs [155]. In terms of MSCs, CD34+-selected stem cell boost, eltrombopag, those efficacies seem to be not so differed; therefore, we should decide the administration order depending on the patient's conditions and other various medical and non-medical factors, considering their advantages and disadvantages. In terms of Tregs administration, this treatment is postponed until the establishment of supplying system of sufficient amount of these cells like MSCs. Alternatively, low-dose IL-2 treatment may be one of the candidates to expand Tregs in vivo. Anti-IFN- $\gamma$ antibody treatment in clinical settings has been just started with favorable responses; however, larger clinical studies are required. Furthermore, although combined treatment with multiple agents may be effective, future clinical trials are warranted. 
Table 2. Possible therapeutic manipulations for graft failure and poor graft function.

\begin{tabular}{|c|c|c|c|c|}
\hline Impaired Hematopoiesis & Chimerism & Initial & Initial & Treatments \\
\hline & & engraftment & hematological & \\
\hline & & & recovery & \\
\hline \multirow[t]{2}{*}{ Primary graft failure } & Mixed/full & - & - & Second transplant \\
\hline & recipient & & & \\
\hline \multirow[t]{6}{*}{ Secondary graft failure } & Mixed/full & + & + & $\mathrm{CD}_{4} 4^{+}$cell boost \\
\hline & recipient & & & Mesenchymal stem cells * \\
\hline & & & & Eltrombopag \\
\hline & & & & Low-dose IL-2 \\
\hline & & & & Anti-IFN- $\gamma$ antibody \\
\hline & & & & Second transplant \\
\hline \multirow[t]{5}{*}{ Primary poor graft function } & Full donor & + & - & $\mathrm{CD} 34^{+}$cell boost, Eltrombopag \\
\hline & & & & Mesenchymal stem cell * \\
\hline & & & & Low-dose IL-2 \\
\hline & & & & Anti-IFN- $\gamma$ antibody \\
\hline & & & & Second transplant \\
\hline \multirow[t]{5}{*}{ Secondary poor graft function } & Full donor & + & + & $\mathrm{CD} 4^{+}$cell boost, Eltrombopag \\
\hline & & & & Mesenchymal stem cell * \\
\hline & & & & Low dose IL-2 \\
\hline & & & & Anti-IFN- $\gamma$ antibody \\
\hline & & & & Second transplant \\
\hline
\end{tabular}

${ }^{*}$ In case of active GVHD and inflammation/infection, mesenchymal stem cells are preferred to be used first.

\section{Conclusions}

Graft failure and poor graft function after allo-HSCT are serious complications. These conditions are often seen in GVHD and persistent inflammation/infection. Based on chimerism analysis and evaluation of hematological recovery status, we can accurately recognize the situation in transplanted patients who have either graft failure or poor graft function. Although we need further clinical evidence by reliable studies, administration of MSCs, CD34 ${ }^{+}$-selected stem cell boost, and eltrombopag are potential candidates for treating these conditions at the present.

Author Contributions: M.I. searched the articles and reviews related to this topic and wrote this manuscript based on the previous results. The Author have read and agreed to the published version of the manuscript.

Funding: This research received no external funding.

Conflicts of Interest: The author declares no conflict of interest.

\section{References}

1. Olsson, R.; Remberger, M.; Schaffer, M.; Berggren, D.M.; Svahn, B.M.; Mattsson, J.; Ringdén, O. Graft failure in the modern era of allogeneic hematopoietic SCT. Bone Marrow Transpl. 2013, 48, 537-543. [CrossRef] [PubMed]

2. Olsson, R.F.; Logan, B.R.; Chaudhury, S.; Zhu, X.; Akpek, G.; Bolwell, B.J.; Bredeson, C.N.; Dvorak, C.C.; Gupta, V.; Ho, V.T.; et al. Primary graft failure after myeloablative allogeneic hematopoietic cell transplantation for hematologic malignancies. Leukemia 2015, 29, 1754-1762. [CrossRef] [PubMed]

3. Zhao, Y.; Gao, F.; Shi, J.; Luo, Y.; Tan, Y.; Lai, X.; Yu, J.; Huang, H. Incidence, risk factors, and outcomes of primary poor graft function after allogeneic hematopoietic stem cell transplantation. Biol. Blood Marrow Transpl. 2019, 25, 1898-1907. [CrossRef] [PubMed] 
4. Lee, K.H.; Lee, J.H.; Chi, S.J. Failure of trilineage blood cell reconstitution after initial neutrophil engraftment in patients undergoing allogeneic hematopoietic cell transplantation-frequency and outcomes. Bone Marrow Transpl. 2004, 33, 729-734. [CrossRef] [PubMed]

5. Nakamae, H.; Storer, B.; Sandmaier, B.M.; Maloney, D.G.; Davis, C.; Corey, L.; Storb, R.; Boeckh, M. Cytopenias after day 28 in allogeneic hematopoietic cell transplantation: Impact of recipient/donor factors, transplant conditions and myelotoxic drugs. Haematologica 2011, 96, 1838-1845. [CrossRef]

6. Peralvo, J.; Bacigalupo, A.; Pittaluga, P.A.; Occhini, D.; van Lint, M.T.; Frassoni, F.; Nardelli, E.; Transino, A.; Pantarotto, M.; Marmout, A.M. Poor graft function associated with graft-versus-host disease after allogeneic marrow transplantation. Bone Marrow Transpl. 1987, 2, 279-285.

7. Tsutsumi, Y.; Tanaka, J.; Sugita, J.; Kato, N.; Zhang, L.; Yonezumi, M.; Chiba, K.; Toyoshima, N.; Kondo, T.; Ohta, S.; et al. Analysis of $\mathrm{T}$ cell repertoire and mixed chimerism in a patient with aplastic anemia after allogeneic bone marrow transplantation. Br. J. Haematol. 2002, 118, 136-139. [CrossRef]

8. Pérez-Simón, J.A.; Caballero, D.; Diez-Campelo, M.; Lopez-Pérez, R.; Mateos, G.; Cañizo, C.; Vazquez, L.; Vidriales, B.; Mateos, M.; Gonzalez, M.; et al. Chimerism and minimal residual disease monitoring after reduced intensity conditioning (RIC) allogeneic transplantation. Leukemia 2002, 16, 1423-1431.

9. Bader, P.; Beck, J.; Frey, A.; Schlegel, P.G.; Hebarth, H.; Handgretinger, R.; Einsele, H.; Niemeyer, C.; Benda, N.; Faul, C.; et al Serial and quantitative analysis of mixed hematopoietic chimerism by PCR in patients with acute leukemias allows the prediction of relapse after allogeneic BMT. Bone Marrow Transpl. 1998, 21, 487-495. [CrossRef]

10. Bader, P.; Niethammer, D.; Willasch, A.; Kreyenberg, H.; Klingebiel, T. How and when should we monitor chimerism after allogeneic stem cell transplantation. Bone Marrow Transpl. 2005, 35, 107-119. [CrossRef]

11. Antin, J.H.; Childs, R.; Filipovich, A.H.; Giralt, S.; Mackinnon, S.; Spitzer, T.; Weisdorf, D. Establishment of complete and mixed donor chimerism after allogeneic lymphohematopoietic transplantation: Recommendations from a workshop at the 2001 Tandem Meetings of the International Bone Marrow Transplant Registry and the American Society of Blood and Marrow Transplantation. Biol. Blood Marrow Transpl. 2001, 7, 473-485.

12. Keil, F.; Prinz, E.; Moser, K.; Mannhalter, C.; Kalhs, P.; Worel, N.; Rabitsch, W.; Schulenburg, A.; Mitterbauer, M.; Greinix, H. Rapid establishment of long-term culture-initiating cells of donor origin after nonmyeloablative allogeneic hematopoietic stem-cell transplantation, and significant prognostic impact of donor T-cell chimerism on stable engraftment and progression-free survival. Transplantation 2003, 76, 230-236. [PubMed]

13. Guimond, M.; Busque, L.; Baron, C.; Bonny, Y.; Bélanger, R.; Mattioli, J.; Roy, D.C. Relapse after bone marrow transplantation: Evidence for distinct immunological mechanisms between adult and paediatric populations. Br. J. Haematol. 2000, 109, 130-137. [CrossRef] [PubMed]

14. Matthes-Martin, S.; Lion, T.; Haas, O.A.; Frommlet, F.; Daxberger, H.; Konig, M.; Printz, D.; Scharner, D.; Eichstill, C.; Peters, C.; et al. Lineage-specific chimaerism after stem cell transplantation in children following reduced intensity conditioning: Potential predictive value of NK cell chimaerism for late graft rejection. Leukemia 2003, 17, 1934-1942. [CrossRef] [PubMed]

15. Bornhäuser, M.; Thiede, C.; Platzbecker, U.; Jenke, A.; Helwig, A.; Plettig, R.; Freiberg-Richter, J.; Rölling, C.; Geissler, G.; Lutterbeck, K.; et al. Dose-reduced conditioning and allogeneic hematopoietic stem cell transplantation from unrelated donors in 42 patients. Clin. Cancer Res. 2001, 7, 2254-2262.

16. Baron, F.; Baker, J.E.; Storb, R.; Gooley, T.A.; Sandmaier, B.M.; Maris, M.B.; Maloney, D.G.; Heimfeld, S.; Oparin, D.; Zellmer, E.; et al. Kinetics of engraftment in patients with hematological malignancies given allogeneic hematopoietic cell transplantation after nonmyeloablative conditioning. Blood 2004, 104, 2254-2262. [CrossRef] [PubMed]

17. Miura, Y.; Tanaka, J.; Toubai, T.; Tsutsumi, Y.; Kato, N.; Hirate, D.; Kaji, M.; Sugit, J.; Shigematsu, A.; Iwao, N.; et al. Analysis of donor-type chimerism in lineage-specific cell populations after allogeneic myeloablative and non-myeloablative stem cell transplantation. Bone Marrow Transpl. 2006, 37, 837-843. [CrossRef]

18. Pedini, P.; Cherout, N.; Basire, A.; Simon, S.; Budon, L.; Pourtein, M.; Grondin, S.; Moskovtchenko, P.; Chiaroni, J.; Michel, G.; et al. Evaluation of next-generation sequencing and crystal digital PCR for chimerism monitoring of post-allogeneic hematopoietic stem cell transplantation. Biol. Blood Marrow Transpl. 2020. [CrossRef]

19. Nakamura, H.; Gress, R.E. Graft rejection by cytolytic T cells. Transplantation 1990, 49, 453-458.

20. Kernan, N.A.; Flomenberg, N.; Dupont, B.; O'Reilly, R.J. Graft rejection in recipients of T-cell-depleted HLA-nonidentical marrow transplants for leukemia: Identification of host-derived antidonor allocytotoxic T lymphocytes. Transplantation 1987, 53, 842-847. [CrossRef]

21. Voogt, P.; Fibbe, W.; Mariit, W.; Veenhof, W.; Hamilton, M.; Zwaan, F.; Willemze, R.; van Rood, J.J. Rejection of bone-marrow graft by recipient-derived cytotoxic T lymphocytes against minor histocompatibility antigens. Lancet 1990, 335, 131-134. [CrossRef]

22. Murphy, W.J.; Kumar, V.; Bennett, M. Acute rejection of murine bone marrow allografts by natural killer cells and T cells. Differences in kinetics and target antigens recognized. J. Exp. Med. 1987, 166, 1499-1509. [CrossRef] [PubMed]

23. Murphy, W.; Kumar, V.; Bennett, M. Rejection of bone marrow allografts by mice with severe combined immune deficiency (SCID). Evidence that natural killer cells can mediate the specificity of marrow graft rejection. J. Exp. Med. 1987, 165, 1212-1217. [CrossRef] [PubMed] 
24. Tiberghein, P.; Longo, D.I.; Wine, J.W.; Alvord, W.G.; Reynolds, C.W. Anti-asialo GM1 antiserum treatment of lethally irradiated recipients before bone marrow transplantation: Evidence that recipient natural killer depletion enhances survival, engraftment, and hematopoietic recovery. Blood 1990, 76, 1419-1430. [CrossRef]

25. Bix, M.; Liao, N.S.; Zijlstra, M.; Loring, J.; Jaenisch, R.; Raulet, D. Rejection of class I MHC-deficient haematopoietic cells by irradiated MHC-matched mice. Nature 1991, 349, 329-331. [CrossRef]

26. Ruggeri, L.; Capanni, M.; Urbani, E.; Perruccio, K.; Shlomchik, W.D.; Tosti, A.; Posati, S.; Rogaia, D.; Frassoni, F.; Aversa, F.; et al. Effectiveness of donor natural killer cell alloreactivity in mismatched hematopoietic transplants. Science 2002, 295, 2097-2100. [CrossRef]

27. Westerhuis, G.; Maas, W.G.E.; Willemze, R.; Toes, R.E.M.; Fibbe, W.E. Long-term mixed chimerism after immunologic conditioning and MHC-mismatched stem-cell transplantation is dependent on NK-cell tolerance. Blood 2005, 106, 2215-2220. [CrossRef]

28. Kean, L.S.; Hamby, K.; Koehn, B.; Lee, E.; Coley, S.; Stempora, L.; Adams, A.B.; Heiss, E.; Pearson, T.C.; Larsen, C.P. NK cells mediate costimulation blockade-resistant rejection of allogeneic stem cells during nonmyeloablative transplantation. Am. J. Transpl. 2006, 6, 292-304. [CrossRef]

29. Bloom, M.L.; Wolk, A.G.; Simon-Stoos, K.L.; Bard, J.S.; Chen, J.; Young, N.S. A mouse model of lymphocyte infusion-induced bone marrow failure. Exp. Hematol. 2004, 32, 1163-1172. [CrossRef]

30. Chewning, J.H.; Zhang, W.; Randolph, D.A.; Swindle, C.S.; Schoeb, T.R.; Weaver, C.T. Allogeneic Th1 cells home to host bone marrow and spleen and mediate IFN gamma-dependent aplasia. Biol. Blood Marrow Transpl. 2013, 19, 876-887. [CrossRef]

31. Komatsu, M.; Mammolent, M.; Jones, M.; Jurecic, R.; Sayers, T.J.; Levy, R.B. Antigen-primed CD8+ T cells can mediate resistance, preventing allograft marrow engraftment in the simultaneous absence of perforin-, CD95L-, TNFR1-, and TRAIL-dependent killing. Blood 2003, 101, 3991-3999. [CrossRef] [PubMed]

32. Zimmerman, Z.; Sharty, A.; Deyev, V.; Podack, E.; Mammolenti, M.; Blazar, B.R.; Yagita, H.; Levy, R.B. Effector cells derived from host CD8 memory T cells mediate rapid resistance against minor histocompatibility antigen-mismatched allogeneic marrow grafts without participation of perforin, Fas ligand, and the simultaneous inhibition of 3 tumor necrosis factor family effector pathways. Biol. Blood Marrow Transpl. 2005, 11, 576-586.

33. Sun, K.; Alvarez, M.; Ames, E.; Barao, I.; Chen, M.; Longo, D.L.; Redelman, D.; Murphy, W.J. Mouse NK cell-mediated rejection of bone marrow allografts exhibits patterns consistent with Ly49 subset licensing. Blood 2012, 119, 1590-1598. [CrossRef] [PubMed]

34. Bennett, M.; Taylor, P.A.; Austin, M.; Baker, M.B.; Schook, L.B.; Rutherford, M.; Kumar, V.; Podack, E.R.; Mohler, K.M.; Levy, R.B.; et al. Cytokine and cytotoxic pathways of NK cell rejection of class-deficient bone marrow grafts: Influence of mouse colony environment. Int. Immunol. 1998, 10, 785-790. [CrossRef] [PubMed]

35. Taylor, M.A.; Ward, B.; Schatzle, J.D.; Bennett, M. Perforin- and Fas-dependent mechanisms of natural killer cell-mediated rejection of incompatible bone marrow cell grafts. Eur. J. Immunol. 2002, 32, 793-799. [CrossRef]

36. Shibuya, A.; Campbell, D.; Hannum, C.; Yssei, H.; Franz-Bacon, K.; McClanahan, T.; Kitamura, T.; Nicholl, J.; Sutherland, G.R.; Lanier, L.L.; et al. DNAM-1, a novel adhesion molecule involved in the cytolytic function of T lymphocytes. Immunity 1996, 4 , 573-581. [CrossRef]

37. Bottino, C.; Castriconi, R.; Pende, D.; Rivera, P.; Nanni, M.; Carnemolla, B.; Cantoni, C.; Grassi, J.; Marcenaro, S.; Reymond, N.; et al. Identification of PVR (CD155) and Nectin-2 (CD112) as cell surface ligands for the human DNAM1 (CD226) activating molecule. J. Exp. Med. 2003, 198, 557-567. [CrossRef]

38. Houchins, J.P.; Yabe, T.; McSherry, C.; Bach, F.H. DNA sequence analysis of NKG2, a family of related cDNA clones encoding type II integral membrane proteins on human natural killer cells. J. Exp. Med. 1991, 173, 1017-1020. [CrossRef]

39. Carapito, R.; Bahram, S. Genetics, genomics, and evolutionary biology of NKG2D ligands. Immunol. Rev. 2015, 267, 88-116. [CrossRef]

40. Müller, A.M.S.; Linderman, J.A.; Florek, M.; Miklos, D.; Shizuru, J.A. Allogeneic T cells impair engraftment and hematopoiesis after stem cell transplantation. Proc. Natl. Acad. Sci. USA 2010, 107, 14721-14726.

41. Urbiera, M.; Barao, I.; Jones, M.; Jurecic, R.; Panoskaltsis-Mortari, A.; Blazar, B.R.; Murphy, W.J.; Levy, R.B. Hematopoietic progenitor cell regulation by $\mathrm{CD} 4{ }^{+} \mathrm{CD} 25^{+} \mathrm{T}$ cells. Blood 2010, 115, 4934-4943. [CrossRef] [PubMed]

42. Barao, I.; Hanash, A.M.; Hallett, W.; Welniak, L.A.; Sun, K.; Redelman, D.; Blazar, B.R.; Levy, R.B.; Murphy, W.J. Suppression of natural killer cell-mediated bone marrow cell rejection by $\mathrm{CD} 4{ }^{+} \mathrm{CD} 25^{+}$regulatory T cells. Proc. Natl. Acad. Sci. USA 2006, 103, 5460-5465. [CrossRef] [PubMed]

43. Joffre, O.; Santolaria, T.; Calise, D.; Saati, T.A.; Hudrisier, D.; Romagnoli, P.; van Meerwijk, J.P.M. Prevention of acute and chronic allograft rejection with $\mathrm{CD}^{+} \mathrm{D} 25^{+} \mathrm{Foxp}^{+}$regulatory T lymphocytes. Nat. Med. 2008, 14, 88-92. [CrossRef] [PubMed]

44. Müller, A.M.; Poyser, J.; Küpper, N.J.; Burnett, C.; Ko, R.M.; Kohrt, H.E.; Florek, M.; Zhang, P.; Nrgrin, R.S.; Shizuru, J.A. Donor hematopoiesis in mice following total lymphoid irradiation requires host T-regulatory cells for durable engraftment. Blood 2014, 123, 2882-2892. [CrossRef]

45. Fujisaki, J.; Wu, J.; Carlson, A.L.; Silberstein, L.; Putheti, P.; Larocca, R.; Gao, W.; Saito, T.I.; Celso, C.L.; Tsuyuzaki, H.; et al. In vivo imaging of Treg cells providing immune privilege to the haematopoietic stem cell niche. Nature 2011, 474, 216-219. [CrossRef]

46. Camacho, V.; Matkins, V.R.; Patel, S.B.; Lever, J.M.; Yang, Z.; Ying, L.; Landuyt, A.E.; Dean, E.C.; George, J.F.; Yang, H.; et al. Bone marrow Tregs mediate stromal function and support hematopoiesis via IL-10. JCI Insight 2020, 5, e135681. [CrossRef]

47. Steiner, D.; Brunicki, N.; Blazar, B.R.; Bachar-Lustig, E.; Reisner, Y. Tolerance induction by third-party "off-the-shelf" CD4 ${ }^{+}$CD25 ${ }^{+}$ Treg cells. Exp. Hematol. 2006, 34, 66-71. [CrossRef] 
48. Koreth, J.; Matsuoka, K.; Kim, H.T.; McDonough, S.M.; Bindra, B.; Alyea, E.P., III; Armand, P.; Cutler, C.; Ho, V.T.; Treister, N.S.; et al. Interleukin-2 and regulatory T cells in graft-versus-host disease. N. Engl. J. Med. 2011, 365, 2055-2066. [CrossRef]

49. Matsuoka, K.; Koreth, J.; Kim, H.T.; Bascug, G.; McDonough, S.; Kawano, Y.; Murase, K.; Cutler, C.; Ho, V.T.; Alyea, E.P.; et al. Low-dose interleukin-2 therapy restores regulatory $\mathrm{T}$ cell homeostasis in patients with chronic graft-versus-host disease. Sci. Transl. Med. 2013, 5, 179ra43. [CrossRef]

50. Xhao, X.Y.; Zhao, X.S.; Wang, Y.T.; Chen, Y.H.; Xu, L.P.; Zhang, X.H.; Han, W.; Chen, H.; Wang, Y.; Yan, C.H.; et al. Prophylactic use of low-dose interleukin-2 and the clinical outcomes of hematopoietic stem cell transplantation: A randomized study. Oncoimmunology 2016, 5, e1250992.

51. Betts, B.C.; Pidala, J.; Kim, J.; Mishra, A.; Nishihori, T.; Perez, L.; Ochoa-Bayona, J.L.; Khimani, F.; Walton, K.; Bookout, R.; et al. IL-2 promotes early Treg reconstitution after allogeneic hematopoietic cell transplantation. Haematologica 2017, 102, 948-957. [CrossRef] [PubMed]

52. Shatry, A.; Levy, R.B. In situ activation and expansion of host Tregs: A new approach to enhance donor chimerism and stable engraftment in major histocompatibility complex-matched allogeneic hematopoietic cell transplantation. Biol. Blood Marrow Transpl. 2009, 15, 785-794. [CrossRef] [PubMed]

53. Bruinsma, M.; van Soest, P.L.; Leenen, P.J.M.; Lowenberg, B.; Cornelissen, J.J.; Braakman, E. Keratinocyte growth factor imprives allogeneic bone marrow engraftment through a CD4+Foxp3+ regulatory T cell-dependent mechanism. J. Immunol. 2009, 182, 7364-7369. [CrossRef] [PubMed]

54. Sakaguchi, S.; Ono, M.; Setoguchi, R.; Yagi, H.; Hori, S.; Fehervari, Z.; Shimizu, J.; Takahashi, T.; Nomura, T. Foxp3+CD25+CD4+ natural regulatory $\mathrm{T}$ cells in dominant self-tolerance and autoimmune disease. Immunol. Rev. 2006, 212, 8-27. [CrossRef] [PubMed]

55. Ringden, O.; Gustafsson, B.; Sadeghi, B. Msenchymal stromal cells in pediatric hematopoietic cell transplantation a review and a pilot study in children treated with decidua stromal cells for acute graft-versus-host disease. Front. Immunol. 2020, 11, 567210. [CrossRef] [PubMed]

56. Le Blanc, K.; Mougiakakos, D. Multipotent mesenchymal stromal cells and the innate immune system. Nat. Rev. Immunol. 2012, 12, 383-396. [CrossRef]

57. Le Blanc, K.; Tammik, C.; Rosendahl, K.; Zetterberg, E.; Ringdén, O. HLA expression and immunologic properties of differentiated and undifferentiated mesenchymal stem cells. Exp. Hematol. 2003, 31, 890-896. [CrossRef]

58. Aggrawal, S.; Pittenger, M.F. Human mesenchymal stem cells modulate allogeneic immune cell response. Blood 2005, 105, 1815-1822. [CrossRef]

59. Di Nicola, M.; Carlo-Stella, C.; Magni, M.; Milanesi, M.; Longoni, P.D.; Matteucci, P.; Grisanti, S.; Gianni, A.M. Human bone marrow stromal cells suppress T-lymphocyte proliferation induced by cellular or nonspecific mitogenic stimuli. Blood 2002, 99, 3838-3843. [CrossRef]

60. Meisel, R.; Zibert, A.; Laryea, M.; Göbel, U.; Däubener, W.; Dilloo, D. Human bone marrow stromal cells inhibit allogeneic T-cell responses by indoleamine 2,3-dioxygenase mediated tryptophan degradation. Blood 2004, 103, 4619-4621. [CrossRef]

61. Francois, M.; Romieu-Mourez, R.; Li, M.; Galpeau, J. Human MSC suppression correlates with cytokine induction of indoleamine 2,3-dioxygenase and bystander M2 macrophage differentiation. Mol. Ther. 2011, 20, 187-195. [CrossRef] [PubMed]

62. Jiang, X.X.; Zhag, Y.Z.; Liu, B.; Zhang, S.X.; Wu, Y.; Yu, X.D.; Mao, N. Human mesenchymal stem cells inhibit differentiation and function of monocyte-derived dendritic cells. Blood 2005, 10, 4120-4126. [CrossRef] [PubMed]

63. Corcione, A.; Benvenuto, F.; Ferretti, E.; Giunti, D.; Cappiello, V.; Cazzanti, F.; Risso, M.; Gualandi, F.; Mancardi, G.L.; Pistoia, V.; et al. Human mesenchymal stem cell modulate HLB-cell functions. Blood 2006, 107, 367-372. [CrossRef] [PubMed]

64. Selmani, Z.; Naji, A.; Zidi, I.; Favier, B.; Gaiffe, E.; Obert, L.; Borg, C.; Saas, P.; Tiberghien, P.; Rouas-Freiss, N.; et al. Human leukocyte antigen-G5 secretion by human mesenchymal stem cells is required to suppress T lymphocyte and natural killer function and to induce CD4+CD25highFOXP3+ regulatory T cells. Stem Cells 2008, 26, 212-222. [CrossRef]

65. Duffy, M.M.; Pindajakova, J.; Hanley, S.A.; McCarthy, C.; Weidhofer, G.A.; Sweeney, E.M.; Englsih, K.; Shaw, G.; Murphy, J.M.; Barry, F.R.; et al. Mesenchymal stem cell inhibition of T-helper 17 cell-differentiation is triggered by cell-cell contact and mediated by prostaglandin E2 via the EP4 receptor. Eur. J. Immunol. 2011, 41, 2840-2851. [CrossRef]

66. Friedenstein, A.J.; Latzinik, N.W.; Grosheva, A.G.; Gorskaya, U.F. Exp. Hematol. 1982, 10, $217-227$.

67. Muguruma, Y.; Yahata, T.; Miyatake, H.; Sato, T.; Uno, T.; Itoh, J.; Kato, S.; Ito, M.; Hotta, T.; Ando, K. Reconstitution of the functional human hematopoietic microenvironment derived from human mesenchymal stem cells in the murine bone marrow compartment. Blood 2006, 107, 1878-1887. [CrossRef]

68. Mendes, S.C.; Robin, C.; Dzierzak, E. Mesenchymal progenitor cells localize within hematopoietic sites throughout ontogeny. Development 2005, 132, 1127-1136. [CrossRef]

69. Almeida-Porada, G.; Porada, C.D.; Tran, N.; Zanjani, E.D. Cotransplantation of human stromal cell progenitors into preimmune fetal sheep results in early appearance of human donor cells in circulation and boosts cell levels in bone marrow at later time points after transplantation. Blood 2000, 95, 3620-3627. [CrossRef]

70. Lazarus, H.M.; Koc, O.N.; Devine, S.M.; Curtin, P.; Maziarz, R.T.; Holland, H.K.; Shpall, E.J.; McCarthy, P.; Atkinson, K.; Cooper, B.W.; et al. Cotransplantation of HLA-identical sibling culture-expanded mesenchymal stem cells and hematopoietic stem cells in hematologic malignancy patients. Biol. Blood Marrow Transpl. 2005, 11, 389-398. [CrossRef] 
71. Ball, L.M.; Bernardo, M.E.; Roelos, H.; Lankester, A.; Cometa, A.; Egeler, R.M.; Locatelli, F.; Fibbe, W.E. Cotransplantation of ex vivo expand mesenchymal stem cells accelerates lymphocyte recovery and may reduce the risk of graft failure in haploidentical hematopoietic stem-cell transplantation. Blood 2007, 110, 2764-2767. [CrossRef] [PubMed]

72. Macmillan, M.L.; Blazar, B.R.; DeFor, T.E.; Wagner, J.E. Transplantation of ex-vivo culture-expanded parental haploidentical mesenchymal stem cells to promote engraftment in pediatric recipients of unrelated donor umbilical cord blood: Results of a phase I-II clinical trial. Bone Marrow Transpl. 2009, 43, 447-454. [CrossRef] [PubMed]

73. Meuleman, N.; Tondreau, T.; Ahmad, I.; Kwan, J.; Crokaert, F.; Delforge, A.; Dorval, C.; Martiat, P.; Lewalle, P.; Lagneaux, L.; et al. Infusion of mesenchymal stromal cells can aid hematopoietic recovery following allogeneic hematopoietic stem cell myeloablative transplant: A pilot study. Stem Cells Dev. 2009, 18, 1247-1252. [CrossRef] [PubMed]

74. Ringdén, O. Mesenchymal stromal cells as first-line treatment of graft failure after hematopoietic stem cell transplantation. Stem Cells Dev. 2009, 18, 1243-1246. [CrossRef] [PubMed]

75. Liu, K.; Chen, Y.; Zeng, Y.; Liu, D.; Chen, H.; Zhang, X.; Han, W.; Wang, Y.; Xhao, T.; Wang, J.; et al. Coinfusion of mesenchymal stromal cells facilitates platelet recovery without increasing leukemia recurrence in haploidentical hematopoietic stem cell transplantation: A randomized, controlled clinical study. Stem Cells Dev. 2011, 20, 1679-1685. [CrossRef] [PubMed]

76. Cillioni, D.; Carlo-Stella, C.; Sammarelli, G.; Regazzi, E.; Colla, S.; Rizzoli, V.; Aversa, F.; Martelli, M.F.; Tabilio, A. Limited engraftment capacity of bone marrow-derived mesenchymal cells following T-cell-depleted hematopoietic stem cell transplantation. Blood 2000, 96, 3637-3643. [CrossRef]

77. Ning, H.; Yang, F.; Jiang, M.; Hu, L.; Feng, K.; Zhang, J.; Yu, Z.; Li, B.; Xu, C.; Li, Y.; et al. The correlation between cotransplantation of mesenchymal stem cells and higher recurrence rate in hematologic malignancy patients: Outcome of a pilot clinical study. Leukemia 2008, 22, 593-599. [CrossRef]

78. Bernardo, M.E.; Ball, L.M.; Cometa, A.M.; Roelofs, H.; Zecca, M.; Avanzini, M.A.; Bertaina, A.; Vinti, L.; Lankester, A.; Maccario, R.; et al. Co-infusion of ex vivo-expanded, parental MSCs prevents life-threatening acute GVHD, but does not reduce the risk of graft failure in pediatric patients undergoing allogeneic umbilical cord blood transplantation. Bone Marrow Transpl. 2011, 46, 200-207. [CrossRef]

79. Ortin, M.; Sierra, J. Use of mesenchymal stem cells as treatment for graft-versus-host disease: Current knowledge and controversies. Immunotherapy 2011, 3, 701-704. [CrossRef]

80. Kallekleiv, M.; Lauren, L.; Bruserud, Ø.; Hatfield, K.J. Co-transplantation of multipotent mesenchymal stromal cells in allogeneic hematopoietic stem cell transplantation: A systemic review and meta-analysis. Cytotherapy 2016, 18, 172-185. [CrossRef]

81. Le Blanc, K.; Frassoni, F.; Ball, L.; Locatelli, F.; Roelofs, H.; Lewis, I.; Lanino, E.; Sundberg, B.; Bernardo, M.E.; Remberger, M.; et al. Mesenchymal stem cells for treatment of steroid-resistant, severe, acute graft-versus-host disease: A phase II study. Lancet 2008, 371, 1579-1586. [CrossRef]

82. Muroi, K.; Miyamura, K.; Okada, M.; Yamashita, T.; Murata, M.; Ishikawa, T.; Uike, N.; Hidaka, M.; Kobayashi, R.; Imamura, M.; et al. Bone marrow-derived mesenchymal stem cells (JR-031) for steroid-refractory grade III or IV acute graft-versus-host disease: A phase II/III study. Int. J. Hematol. 2016, 103, 243-250. [CrossRef] [PubMed]

83. Kurzberg, J.; Abdel-Azim, H.; Carpenter, P.; Chaudhury, S.; Horn, B.; Mahadeo, K.; Nemecek, E.; Neudorf, S.; Prasad, V.; Prockop, S.; et al. MSB-GVH001/002 Study Group. A phase 3, single-arm, prospective study of remestemcel-L, ex vivo cultureexpanded adult human mesenchymal stromal cells for the treatment of pediatric patients who failed to respond to steroid treatment for acute graft-versus-host disease. Biol. Blood Marrow 2020, 26, 845-854.

84. Ringden, O.; Baygan, A.; Remberger, M.; Gustafsson, B.; Winiarski, J.; Khoein, B.; Moll, G.; Klingspor, L.; Westgren, M.; Sadeghi, B. Placenta-derived decidua stromal cells for treatment of severe acute graft-versus-host disease. Stem Cells Transl Med. 2018, 7, 325-331. [CrossRef] [PubMed]

85. Ciurea, S.O.; De Lima, M.; Cano, P.; Körbling, M.; Giralt, S.; Shpall, E.J.; Wang, X.; Thall, P.F.; Chhamplin, R.E.; Fernandez-Vina, M. High risk of graft failure in patients with anti-HLA antibodies undergoing haploidentical stem-cell transplantation. Transplantation 2009, 88, 1019-1024. [CrossRef]

86. Yoshihara, S.; Maruya, E.; Taniguchi, K.; Kaida, K.; Kato, R.; Inoue, T.; Fujioka, T.; Tamaki, H.; Ikegame, K.; Okada, M.; et al. Risk and prevention of graft failure in patients with preexisting donor-specific HLA antibodies undergoing unmanipulated haploidentical SCT. Bone Marrow Transpl. 2012, 47, 508-515. [CrossRef]

87. Chang, Y.J.; Zhao, X.Y.; Xu, L.P.; Zhang, X.H.; Wang, Y.; Han, W.; Chen, H.; Wang, F.R.; Mo, X.D.; Zhang, Y.Y.; et al. Donor-specific anti-human leukocyte antigen antibodies were associated with primary graft failure after unmanipulated haploidentical blood and marrow transplantation: A prospective study with randomly assigned training and validation sets. J. Hematol. Oncol. 2015, 8, 84. [CrossRef]

88. Gladstone, D.E.; Zachary, A.A.; Fuchs, E.P.; Luznik, L.; Kasamon, Y.L.; King, K.E.; Brodsky, R.A.; Jones, R.J.; Leffell, M.S. Partially mismatched transplantation and human leukocyte antigen donor-specific antibodies. Biol. Blood Marrow Transpl. 2013, 19, 647-652. [CrossRef]

89. Leffell, M.S.; Jones, R.J.; Gladstone, D.E. Donor HLA-specific Abs: To BMT or not to BMT? Bone Marrow Transpl. 2015, 50, 751-758. [CrossRef]

90. Ciurea, S.O.; Cao, K.; Fernandez-Vina, M.; Kongtim, P.; Malki, M.A.; Fuchs, E.; Luznik, L.; Huang, X.J.; Ciceri, F.; Locatelli, F.; et al. The European Society for Blood and Marrow Transplantation (EBMT) concensus guidelines for the detection and treatment of donor-specific anti-HLA antibodies (DSA) in haploidentical hematopoietic cell transplantation. Bone Marrow Transpl. 2018, 53, 521-534. [CrossRef] 
91. Hanajiri, R.; Murata, M.; Sugimoto, K.; Murase, M.; Sakemura, R.; Goto, T.; Watanabe, K.; Imahashi, N.; Terakura, S.; Ohashi, H.; et al. Integration of humoral and cellular HLA-specific immune responses in cord blood allograft rejection. Bone Marrow Transpl. 2015, 50, 1187-1194. [CrossRef]

92. Nordlander, A.; Mattsson, J.; Sundberg, B.; Sumitran-Holgersson, S. Novel anti-bodies to the donor stem cell population CD34+/VEGFR-2+ are associated with rejection after hematopoietic stem cell transplantation. Transplantation 2008, 86, 686-696. [CrossRef]

93. Mori, T.; Nishimura, T.; Ikeda, Y.; Hotta, T.; Yagita, H.; Ando, K. Involvement of Fas-mediated apoptosis in the hematopoietic progenitor cells of graft-versus-host reaction-associated myelosuppression. Blood 1998, 92, 101-107. [CrossRef] [PubMed]

94. Delisle, J.S.; Gaboury, L.; Bélanger, M.P.; Tassé, E.; Yagita, H.; Perreault, C. Graft-versus-host disease causes failure of donor hematopoiesis and lymphopoiesis in interferon-gamma receptor-deficient hosts. Blood 2008, 112, 2111-2119. [CrossRef] [PubMed]

95. Welniak, L.A.; Blazar, B.R.; Anver, M.R.; Wiltrout, R.H.; Murphy, W.J. Opposing roles of interferon-gamma on CD4 ${ }^{+} \mathrm{T}$ cellmediated graft-versus-host disease: Effects of conditioning. Biol. Blood Marrow Transpl. 2000, 6, 604-612. [CrossRef]

96. Rottman, M.; Soudais, C.; Vogt, G.; Renia, L.; Emile, J.F.; Decaluwe, H.; Gaillard, J.L.; Casanova, J.L. IFN-gamma mediates the rejection of hematopoietic stem cells in IFN-gamma R1-deficient hosts. PLoS Med. 2008, 5, e26. [CrossRef]

97. Lin, Y.; Hu, X.; Cheng, H.; Pang, Y.; Wang, L.; Zou, L.; Xu, S.; Zhuang, X.; Jiang, C.; Yuan, W.; et al. Graft-versus-host disease causes broad suppression of hematopoietic primitive cells and blocks megakaryocyte differentiation in a murine model. Biol. Blood Marrow Transpl. 2014, 20, 1290-1300. [CrossRef]

98. Chen, J.; Feng, X.; Desierto, M.; Keyvanfar, K.; Young, N.S. IFN-g-mediated hematopoietis cell destruction in murine models of immune-mediated bone marrow failure. Blood 2015, 126, 2621-2631. [CrossRef]

99. Merli, P.; Caruana, I.; De Vito, R.; Strocchio, L.; Weber, G.; Del Bufalo, F.; Buatois, V.; Montanari, P.; Cefalo, M.G.; Pitiscim, A.; et al. Role of interferon- $\gamma$ in immune-mediated graft failure after allogeneic hematopoietic stem cell transplantation. Haematologica 2019, 104, 2314-2323. [CrossRef]

100. Wang, Y.T.; Kong, Y.; Song, Y.; Han, W.; Zhang, Y.Y.; Zhang, X.H.; Chang, Y.J.; Jiang, Z.F.; Huang, X.J. Increased type 1 immune response in the bone marrow immune microenvironment of patients with poor graft function after allogeneic hematopoietic stem cell transplantation. Biol. Blood Marrow Transpl. 2016, 22, 1376-1382. [CrossRef]

101. Tucci, F.; Gallo, V.; Barzaghi, F.; Ferrua, F.; Migliavacca, M.; Calbi, V.; Doglio, M.; Fratini, E.S.; Karakas, Z.; Guner, S.; et al. Treatment with emapalumab in an ADA-SCID patient with refractory hemophagocytic lymphohistiocytosis-related graft failure and disseminated BCGitis. Haematologica 2020. [CrossRef] [PubMed]

102. Zoumbos, N.; Djeu, J.; Young, N. Interferon is the suppressor of hematopoiesis generated by stimulated lymphocytes in vitro. J. Imunol. 1984, 133, 769-774.

103. Yu, J.M.; Emmons, R.V.; Hanazono, Y.; Sellers, S.; Young, N.S.; Dunbar, C.E. Expression of interferon- $\gamma$ by stromal cells inhibits murine long-term repopulating hematopoietic stem cell activity. Exp. Hematol. 1999, 27, 895-903. [CrossRef]

104. Snoeck, H.W.; van Bockstaele, D.; Nys, G.; Leniou, M.; Lardon, F.; Haenen, L.; Rodrigus, I.; Peetermans, M.E.; Berneman, Z.N. Interferon gamma selectively inhibits very primitive $\mathrm{CD} 342^{+} \mathrm{CD} 38^{-}$-and not more mature $\mathrm{CD} 34^{+} \mathrm{CD} 8^{+}$human hematopoietic progenitor cells. J. Exp. Med. 1994, 180, 1177-1182. [CrossRef] [PubMed]

105. Yang, L.; Dybedal, I.; Bryder, D.; Nilsson, L.; Sitnicka, E.; Sasaki, Y.; Jacobsoen, S.E.W. IFN-gamma negatively modulates self-renewal of repopulating human hematopoietic stem cells. J. Immunol. 2005, 174, 752-757. [CrossRef] [PubMed]

106. Zeng, W.; Miyazato, A.; Chen, G.; Kajigaya, S.; Young, N.S.; Maciejewski, J.P. Interferon- $\gamma$-induced gene exprression in CD34 cells: Identification of pathologic cytokine-specific signature profiles. Blood 2006, 107, 167-175. [CrossRef]

107. Maciejewski, J.; Selleri, C.; Anderson, S.; Young, N. Fas antigen expression on CD34 ${ }^{+}$human marrow cells is induced by inteferon gamma and tumor necrosis factor alpha and potentiates cytokine-mediated hematopoietic suppression in vitro. Blood 1995, 85, 3183-3190. [CrossRef]

108. de Bruin, A.M.; Demirel, Ö.; Hooibrink, B.; Brandts, C.H.; Nolte, M.A. Interferon- $\gamma$ impairs proliferation of hematopoietic stem cells in mice. Blood 2013, 121, 3578-3585. [CrossRef]

109. Broxmeyer, H.E.; Williams, D.E.; Lu, L.; Cooper, S.; Anderson, S.L.; Beyer, G.S.; Hoffman, R.; Rubin, B.Y. The suppressive influences of human tumor necrosis factors on bone marrow hematopoietic progenitor cells from normal donors and patients with leukemia: Synergism of tumor necrosis factor and interferon-gamma. J. Immunl. 1986, 136, 4487-4495.

110. Backx, B.; Broeders, L.; Bot, F.J.; Lowenberg, B. Positive and negative effects of tumor necrosis factor on colony growth from highly purified normal marrow progenitors. Leukemia 1991, 5, 66-70.

111. Rusten, L.S.; Jacobsen, F.W.; Lesslauer, W.; Loetscher, H.; Smeland, E.B.; Jacobsen, S.E. Bifunctional effects of tumor necrosis factor alpha (TNF alpha) on the growth of mature and primitive human hematopoietic progenitor cells: Involvement of p55 and p75 TNF receptors. Blood 1994, 83, 3152-3159. [CrossRef] [PubMed]

112. Zhang, Y.; Harada, A.; Bluethmann, H.; Wang, J.B.; Nakao, S.; Mukaida, N.; Matsushima, K. Tumor necrosis factor (TNF) is a physiologic regulator of hematopoietic progenitor cells: Increase of early hematopoietic progenitor cells in TNF receptor p55-deficient mice in vivo and potent inhibition of progenitor cell proliferation by TNF alpha in vitro. Blood 1995, 86, $2930-2937$. [PubMed]

113. Dybedal, I.; Bryder, D.; Fossum, A.; Rusten, L.S.; Jacobsen, S.E.W. Tumor necrosis factor (TNF)-mediated activation of the p55 TNF receptor negatively regulates maintenance of cycling reconstituting human hematopoietic stem cells. Blood 2001, 98, 1782-1791. [CrossRef] [PubMed] 
114. Pronk, C.J.; Veiby, O.P.; Bryder, D.; Jacobsen, S.E. Tumor necrosis factor restricts hematopoietic stem cell activity in mice: Involvement of two distinct receptors. J. Exp. Med. 2011, 208, 1563-1570. [CrossRef]

115. Senyuk, V.; Patel, P.; Mahmud, N.; Rondelli, D. Blockade of TNF $\alpha$ to improve human CD34 ${ }^{+}$cell repopulating activity in allogeneic stem cell transplantation. Front. Immunol. 2019, 9, 3186. [CrossRef]

116. Sun, W.; Wu, Z.; Lin, Z.; Hollinger, M.; Chen, J.; Feng, X.; Young, N.S. Macrophag TNF- $\alpha$ licenses donor T cells in murine bone marrow failure and can be implicated in human aplastic anemia. Blood 2018, 132, 2730-2743. [CrossRef]

117. Levine, J.E.; Paczesny, S.; Mineishi, S.; Braun, T.; Choi, S.W.; Hutchinson, R.J.; Jones, D.; Khaled, Y.; Kitko, C.L.; Bickley, D.; et al Etanercept plus methylprednisolone as initial therapy for acute graft-versus-host disease. Blood 2008, 111, 2470-2475. [CrossRef]

118. Kennedy, G.A.; Butler, J.; Western, R.; Morton, J.; Durrant, S.; Hill, G.R. Combination antithymocyte globulin and soluble TNFalpha inhibitor (etanercept) +/- mycophenolate mofetil for treatment of steroid refractory acute graft-versus-host disease. Bone Marrow Transpl. 2006, 37, 1143-1147. [CrossRef]

119. Scadden, D.T. The stem-cell niche as an entity of action. Nature 2006, 441, 1075-1079. [CrossRef]

120. Wei, Q.; Frenette, P.S. Niches for hematopoietic stem cells and their progeny. Immunity 2018, 48, 632-650. [CrossRef]

121. Pinho, S.; Frenette, P.S. Haematopoietic stem cell activity and interactions with the niche. Nat. Rev. Mol. Cell Biol. 2019, 20, 303-320. [CrossRef] [PubMed]

122. Ménderez-Ferrer, S.; MIchurina, T.V.; Ferraro, F.; Mazloom, A.R.; MacArthur, B.D.; Lira, S.A.; Scadden, D.T.; Ma'ayan, A.; Enikolopov, G.N.; Frenette, P.S. Mesenchymal and haematopoietic stem cells from a unique bone marrow niche. Nature 2010, 466, 829-834. [CrossRef] [PubMed]

123. Asada, N.; Kunisaki, Y.; Pierce, H.; Wang, Z.; Fernandez, N.F.; Birbrair, A.; Ma'ayan, A.; Frenette, P.S. Diffrential cytokine contributions of perivascular haematopoietic stem cell niches. Nat. Cell Biol. 2017, 19, 214-223. [CrossRef] [PubMed]

124. Sugiyama, T.; Kohara, H.; Noda, M.; Nagasaw, T. Maintenance of the hematopoietic stem cell pool by CXCL12-CXCR4 chemokine signaling in bone marrow stromal cell niches. Immunity 2006, 25, 977-988. [CrossRef]

125. Ding, L.; Saunders, T.L.; Enikolopov, G.; Morrison, S.J. Endothelial and perivascular cells maintain haematopoietic stem cells. Nature 2012, 481, 457-462. [CrossRef]

126. Ménderez-Ferrer, S.; Lucas, D.; Battista, M.; Frenette, P.S. Haematopoietic stem cell release is regulated by circadian oscillations. Nature 2008, 452, 442-447. [CrossRef]

127. Yamazaki, S.; Ema, H.; Karlsson, G.; Yamaguchi, T.; Miyoshi, H.; Shioda, S.; Taketo, M.M.; Karlsson, S.; Iwama, A.; Nakauchi, H. Nonmyelinating Schwann cells maintain hematopoietic stem cell hibernation in the bone marrow niche. Cell 2011, 147, 1146-1158. [CrossRef]

128. Ding, L.; Morrison, S.J. Haematopoietic stem cells and early lymphoid progenitors occupy distinct bone marrow niches. Nature 2013, 495, 231-235. [CrossRef]

129. Naveiras, O.; Nardi, V.; Wenzel, P.L.; Hauschka, P.V.; Fahey, F.; Daley, G.Q. Bone-marrow adipocytes as negative regulators of the haematopoietic microenvironment. Nature 2009, 460, 259-263. [CrossRef]

130. Shono, Y.; Ueha, S.; Wang, Y.; Abe, J.; Kurauchi, M.; Natsuno, Y.; Sugiyama, T.; Nagasawa, T.; Imamura, M.; Matsushima, K. Bone marrow graft-versus-host disease: Early destruction of hematopoietic niche after MHC-mismatched hematopoietic stem cell transplantation. Blood 2010, 11, 5401-5411. [CrossRef]

131. Kunisaki, Y.; Bruns, I.; Scheiermann, C.; Ahmed, J.; Pinho, S.; Zhang, D.; Mizoguchi, T.; Wei, Q.; Lucas, D.; Ito, K.; et al. Arteriolar niches maintain haematopoietic stem cell quiescence. Nature 2013, 502, 637-643. [CrossRef] [PubMed]

132. Nombela-Arrieta, C.; Pivarnik, G.; Winkel, B.; Canty, K.J.; Harley, B.; Mahoney, J.E.; Park, S.Y.; Lu, J.; Protopopov, A.; Silberstein, L.E. Quantitative imaging of haematopoietic stem and progenitor cell localization and hypoxic status in the bone marrow microenvironment. Nat. Cell Biol. 2013, 15, 533-543. [CrossRef] [PubMed]

133. Zhu, J.; Garrett, R.; Jung, Y.; Zhang, Y.; Kim, N.; Wang, J.; Joe, G.J.; Hexner, E.; Choi, Y.; Taichman, R.S.; et al. Osteoblasts support B-lymphocyte commitment and differentiation from hematopoietic stem cells. Blood 2007, 109, 3706-3712. [CrossRef]

134. Baker, M.B.; Riley, R.L.; Podack, E.R.; Levy, R.B. Graft-versus-host disease-associated lymphoid hyperplasia and B cell dysfunction is dependent upon donor T cell-mediated Fas-ligand function, but not perforin function. Proc. Natl. Acad. Sci. USA 1997, 94, 1366-1371. [CrossRef] [PubMed]

135. Storek, J.; Wells, D.; Dawson, M.A.; Storer, B.; Maloney, D.G. Factors influencing Blymphopoiesis after allogeneic hematopoietic cell transplantation. Blood 2001, 98, 489-491. [CrossRef] [PubMed]

136. Sarantopoulos, S.; Stevenson, K.E.; Kim, H.T.; Washhel, W.S.; Bhuiya, N.S.; Cutler, C.S.; Alyea, E.P.; Ho, V.T.; Soiffer, R.J.; Antin, J.H.; et al. Recovery of B-cell homeostasis after rituximab in chronic graft-versus-host disease. Blood 2011, 117, $2275-2283$. [CrossRef] [PubMed]

137. Shono, Y.; Shiratori, S.; Kosugi-Kanaya, M.; Ueha, S.; Sugita, J.; Shigematsu, A.; Kondo, T.; Hashimoto, D.; Fujimoto, K.; Endo, T.; et al. Bone marrow graft-versus-host disease: Evaluation of its clinical impact on disrupted hematopoiesis after allogeneic hematopoietic stem cell transplantation. Biol. Blood Marrow Transpl. 2014, 20, 495-500. [CrossRef] [PubMed]

138. Kong, Y.; Chang, Y.J.; Wang, Y.Z.; Chen, Y.H.; Han, W.; Wang, Y.; Sun, Y.Q.; Yan, C.H.; Wang, F.R.; Liu, Y.R.; et al. Association of an impaired bone marrow microenvironment with secondary poor graft function after allogeneic hematopoietic stem cell transplantation. Biol. Blood Marrow Transpl. 2013, 19, 1465-1473. [CrossRef] 
139. Kong, Y.; Wang, Y.T.; Hu, Y.; Han, W.; Chang, Y.J.; Zhang, X.H.; Jiang, Z.F.; Huang, X.J. The bone marrow microenvironment is similarly impaired in allogeneic hematopoietic stem cell transplantation patients with early and late poor graft function. Bone Marrow Transpl. 2016, 51, 249-255. [CrossRef]

140. Yao, Y.; Song, X.; Cheng, H.; Tang, G.; Hu, X.; Zhou, H.; Wang, J. Dysfunction of bone marrow vascular niche in acute graft-versushost disease after MHC-haploidentical bone marrow transplantation. PLoS ONE 2014, 9, e104607. [CrossRef]

141. Medinger, M.; Krenger, W.; Jakab, A.; Hakter, J.; Buser, A.; Bucher, C.; Passweg, J.; Tzankov, A. Numerical impairment of nestin $(+)$ bone marrow niches in acute GvHD after allogeneic hematopoietic stem cell transplantation for AML. Bone Marrow Transpl. 2015, 50, 1453-1458. [CrossRef] [PubMed]

142. Cao, X.N.; Kong, Y.; Song, Y.; Shi, M.M.; Zhao, H.Y.; Wen, Q.; Lyu, Z.S.; Duan, C.W.; Wang, Y.; Xu, L.P.; et al. Impairment of bone marrow endothelial cells in acute graft-versus -host disease patients after allotransplant. Br. J. Haematol. 2018, 182, 870-886. [CrossRef] [PubMed]

143. Song, Y.; Zhao, H.Y.; Lyu, Z.S.; Cao, X.N.; Shi, M.M.; Wen, Q.; Tang, F.F.; Wang, Y.; Xu, L.P.; Zhang, X.H.; et al. Dysfunctional bone marrow mesenchymal stem cells in patients with poor graft function after allogeneic hematopoietic stem cell transplantation Biol. Blood Marrow Transplant. 2018, 24, 1981-1989. [CrossRef] [PubMed]

144. Zhao, H.Y.; Lyu, Z.S.; Duan, C.W.; Song, Y.; Han, T.T.; Mo, X.D.; Wang, Y.; Xu, L.P.; Zhang, X.H.; Huang, X.J.; et al. An unbalanced monocyte macrophage polarization in the bone marrow microenvironment of patients with poor graft function after allogeneic haematopoietic stem cell transplantation. Brit. J. Haematol. 2018, 182, 679-692. [CrossRef]

145. Kong, Y.; Shi, M.M.; Zhang, Y.Y.; Cao, X.N.; Wang, Y.; Zhang, X.H.; Xu, L.P.; Huang, X.J. N-acetyl-L-cysteine improves bone marrow endothelial progenitor cells in prolonged isolated thrombocytopenia patients post allogeneic hematopoietic stem cell transplantation. Am. J. Hematol. 2018, 93, 931-942. [CrossRef]

146. Kong, Y.; Wang, Y.; Zhang, Y.Y.; Shi, M.M.; Mo, X.D.; Sun, Y.Q.; Chang, Y.J.; Xu, L.P.; Zhang, X.H.; Liu, K.Y.; et al. Prophylactic oral NAC reduced poor hematopoietic reconstitution by improving endothelial cells after haploidentical transplantation. Blood Adv. 2019, 3, 1303-1317. [CrossRef]

147. Shi, M.M.; Kong, Y.; Song, Y.; Sun, Y.Q.; Wang, Y.; Zhang, X.H.; Xu, L.P.; Liu, K.Y.; Huang, X.J. Atorvastatin enhances endothelial cell function in posttransplant poor graft function. Blood 2016, 128, 2988-2999. [CrossRef]

148. Larocca, A.; Piaggio, G.; Podesta, M.; Pitto, A.; Bruno, B.; GRazia, C.D.; Gualandi, F.; Occhini, D.; Raiola, A.M.; Dominietto, A.; et al. Boost of $\mathrm{CD} 34^{+}$-selected peripheral blood cells without further conditioning in patients with poor graft function following allogeneic stem cell transplantation. Haematologica 2006, 9, 935-940.

149. Klyuchnikov, E.; El-Cheikh, J.; Sputtek, A.; Lioznov, M.; Calmels, B.; Furstm, S.; Chabannon, C.; Crocchiolo, R.; Lemarié, C.; Faucher, C.; et al. CD34 ${ }^{+}$-selected stem cell boost without further conditioning for poor graft function after allogeneic stem cell transplantation in patients with hematological malignancies. Biol. Blood Marrow Transpl. 2014, 20, 382-386. [CrossRef]

150. Mainardi, C.; Ebinger, M.; Enkel, S.; Feuchtinger, T.; Teltschik, H.M.; Eryich, M.; Schumm, M.; Rabsteyn, A.; Schlegel, P.; Seitz, C.; et al. CD34+ selected stem cell boosts can improve poor graft function after paediatric allogeneic stem cell transplantation. Brit. J. Haematol. 2018, 180, 90-99. [CrossRef]

151. Mohty, R.; Brissot, E.; Battipaglia, G.; Ruggeri, A.; Sestili, S.; Mediavilla, C.; Belhocine, R.; Dulery, R.; Mohty, M.; Malard, F. $\mathrm{CD} 34^{+}$-selected stem cell "boost" for poor graft function after allogeneic hematopoietic stem cell transplantation. Curr. Res. Transl. Med. 2019, 67, 112-114. [CrossRef] [PubMed]

152. Cuadrado, M.M.; Szydlo, R.M.; Watts, M.; Patel, N.; Renshaw, H.; Dorman, J.; Lowdell, M.; Ings, S.; Anthias, C.; Madrigal, A.; et al. Predictors of recovery following allogeneic CD34 ${ }^{+}$-selected cell infusion without conditioning to correct poor graft function. Haematologica 2019, 105, 2639-2646. [CrossRef] [PubMed]

153. Bussel, J.B.; Cheng, G.; Saleh, M.N. Eltrombopag for the treatment of chronic idiopathic thrombocytopenic purpura. N. Engl. J. Med. 2007, 357, 2237-2247. [CrossRef] [PubMed]

154. Townsley, D.M.; Scheinberg, P.; Winkler, T.; Desmond, R.; Dumitriu, B.; Rios, O.; Weinstein, B.; Valdez, J.; Lotter, J.; Feng, X.; et al. Eltrombopag added to standard immunosuppression for aplastic anemia. N. Engl. J. Med. 2017, 376, 1540-1550. [CrossRef]

155. Vince, A.; Patel, B.A.; Gutierrez-Rodrigues, F.; Groarke, E.; Giudice, V.; Lotter, J.; Feng, X.; Kagigaya, S.; Weinstein, B.; Barranta, E.; et al. Eltrombopag momnotherapy can improve hematopoiesis in patients with low to intermediate risk-1 myelodysplastic syndrome. Haematologica 2020, 105. [CrossRef]

156. Marotta, S.; Marano, L.; Ricci, P.; Cacace, F.; Frieri, C.; Simeone, L.; Trastulli, F.; Vitiello, S.; Cardano, F.; Pane, F.; et al. Eltrombopag for post-transplant cytopenias due to poor graft function. Bone Marrow Transpl. 2019, 54, 1346-1353. [CrossRef]

157. Fu, H.; Zhang, X.; Han, T.; Mo, X.; Wang, Y.; Chen, H.; Han, W.; Wang, J.; Wang, F.; Yan, C. Eltrombopag is an effective and safe therapy for refractory thrombocytopenia after haploidentical hematopoietic stem cell transplantation. Bone Marrow Transpl. 2019, 54, 1310-1318. [CrossRef]

158. Yuan, C.; Boyd, A.M.; Nelson, J.; Patel, R.; Varela, J.C.; Goldstein, S.C.; Ahmad, S.; Zhu, X.; Mori, S. Eltrombopag for treating thrombocytopenia after allogeneic stem cell transplantation. Biol. Blood Marrow Transpl. 2019, 25, 1320-1324. [CrossRef]

159. Méndez-Ferrer, S.; Bonnet, D.; Steensma, D.P.; Hasserjian, R.P.; Ghobrial, I.M.; Gribben, J.G.; Andreeff, M.; Krause, D.S. Bone marrow niches in haematological malignancies. Nat. Rev. Cancer 2020, 20, 285-298. [CrossRef]

160. Golan, K.; Singh, A.K.; Kollet, O.; Bertagna, M.; Althoff, M.J.; Khatib-Massalha, E.; Petrovich-Kopitman, E.; Wellendorf, A.M.; Massalha, H.; Levin-Zaidman, S.; et al. Bone marrow regeneration requires mitochondrial transfer from donor Cx43-expressing hematopoietic progenitors to stroma. Blood 2020, 136, 2607-2619. [CrossRef] 
161. Islam, M.N.; Das, S.R.; Emin, M.T.; Wei, M.; Sun, L.; Westphalen, K.; Rowlands, D.J.; Quadri, S.K.; Bhattacharya, S.; Bhattacharya, J. Mitochondrial transfer from bone-marrow-derived stromal cells to pulmonary alveoli protects against acute lung injury. Nat. Med. 2012, 18, 759-765. [CrossRef] [PubMed]

162. Mistry, J.J.; Marlein, C.R.; Moore, J.A.; Hellmich, C.; Wojtowicz, E.E.; Smith, J.G.W.; Macaulay, I.; Sun, Y.; Morfakis, A.; Patterson, A.; et al. ROS-mediated PI3K activation drives mitochondrial transfer from stromal cells to hematopoietic stem cells in response to infection. Proc. Natl. Acad. Sci. USA 2019, 116, 24610-24619. [CrossRef] [PubMed]

163. Taniguchi Ishikawa, E.; Gonzalez-Nieto, D.; Ghiaur, G.; Dunn, S.K.; Ficker, A.M.; Murali, B.; Madhu, M.; Gutstein, D.E.; Fishman, G.I.; Barrio, L.C.; et al. Connexin-43 prevents hematopoietic stem cell senescence through transfer of reactive oxygen species to bone marrow stromal cells. Proc. Natl. Acad. Sci. USA 2012, 109, 9071-9076. [CrossRef] [PubMed] 